Universidade de Brasília (UnB)

Faculdade UnB de Planaltina (FUP)

Programa de Pós-Graduação em Gestão Pública (PPGP)

Mestrado Profissional em Gestão Pública

FRANCISCO DE ASSIS COSTA E SILVA

\title{
ANÁliSE DA UTILIZAÇÃO DO SISTEMA ÚNICO DE SAÚDE POR SERVIDORES PÚBLICOS FEDERAIS QUE POSSUEM PLANOS PRIVADOS DE SAÚDE
}




\title{
ANÁLISE DA UTILIZAÇÃO DO SISTEMA ÚNICO DE SAÚDE POR SERVIDORES PÚBLICOS FEDERAIS QUE POSSUEM PLANOS PRIVADOS DE SAÚDE
}

\author{
Dissertação apresentada ao Programa de \\ Mestrado Profissional em Gestão Pública da \\ Faculdade UnB de Planaltina como parte dos \\ requisitos para obtenção do título de Mestre \\ em Gestão Pública. \\ Linha de Pesquisa: Instrumentos de \\ Monitoramento e Avaliação da Gestão Pública \\ Orientadora: Profa. Dra. Maria Raquel Gomes Maia Pires
}

Brasília - DF 
Silva, Francisco de Assis Costa e

SSI586a ANÁLISE DA UTILIZAÇÃO DO SISTEMA ÚNICO DE SAÚDE POR SERVIDORES PÚBLICOS FEDERAIS QUE POSSUEM PLANOS PRIVADOS DE SAÚDE / Francisco de Assis Costa e Silva; orientadora: Maria Raquel Gomes Maia Pires. -- Brasília, 2016. $87 \mathrm{p}$.

Dissertação (Mestrado - Mestrado Profissional em Gestão Pública) - Universidade de Brasília, 2016.

1. Saúde suplementar. 2. Plano privado de saúde. 3. Auxílio-saúde. 4. Renúncia fiscal. 5. Ressarcimento ao SUS. I. Pires, Maria Raquel Gomes Maia, orient. II. Título. 
FRANCISCO DE ASSIS COSTA E SILVA

Dissertação apresentada ao Programa de Mestrado Profissional em Gestão Pública da Faculdade UnB de Planaltina como parte dos requisitos para obtenção do título de Mestre em Gestão Pública.

Aprovada em 26 de abril de 2016.

BANCA EXAMINADORA

\title{
ANÁLISE DA UTILIZAÇÃO DO SISTEMA ÚNICO DE SAÚDE POR SERVIDORES PÚBLICOS FEDERAIS QUE POSSUEM PLANOS PRIVADOS DE SAÚDE
}

\author{
Profa. Dra. Maria Raquel Gomes Maia Pires \\ Orientadora \\ Programa de Pós-Graduação em Gestão Pública - Faculdade UnB de Planaltina (FUP)
}

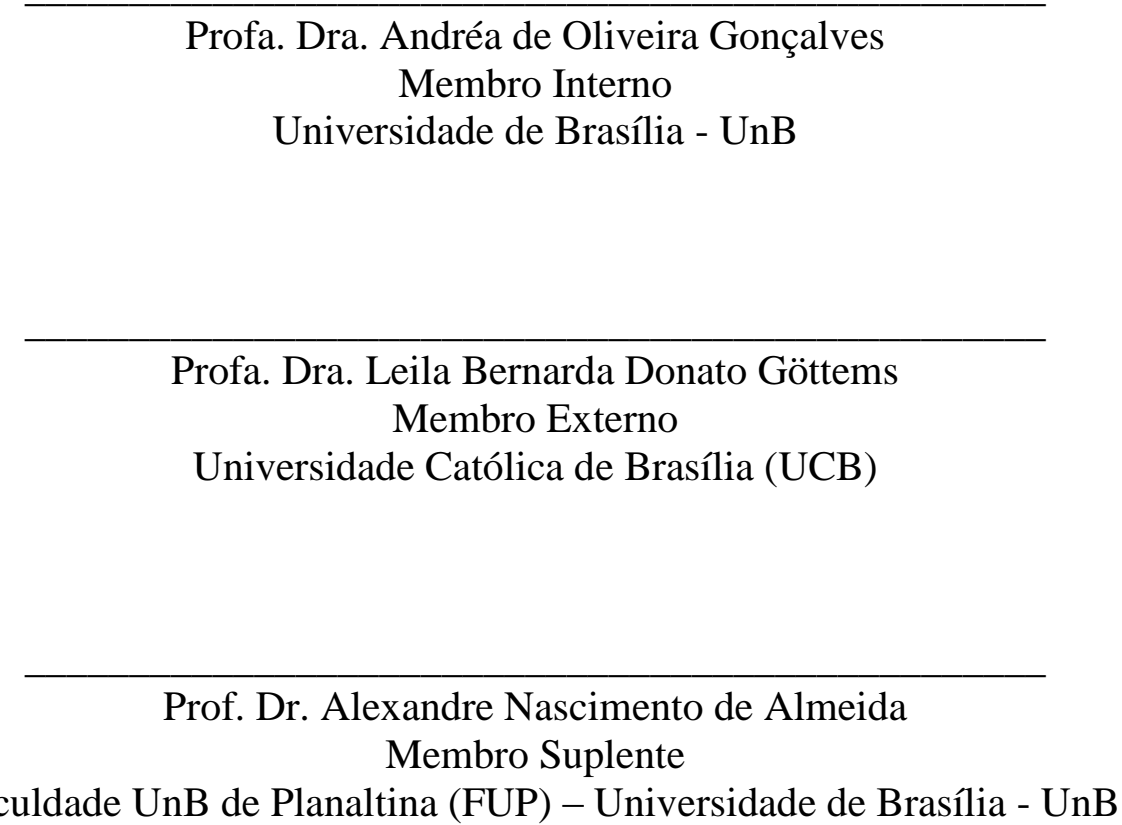


A Deus, a Irma Lúcia Ferreira Rufino (minha mãe e maior incentivadora), a todos os familiares, amigos e demais pessoas que contribuíram para o sucesso desta preciosa jornada acadêmica. 


\section{AGRADECIMENTOS}

A Deus, por tudo que conquistei por meio dos estudos.

À minha orientadora, Profa. Dra. Maria Raquel Gomes Maia Pires, pelos ensinamentos, incentivos, críticas, que me fizeram evoluir; pela permanente colaboração e pela confiança depositada em mim, sem os quais esta obra não teria êxito.

A todos os professores, pelos ensinamentos e apoio dentro e fora do ambiente acadêmico, tais como suporte via celular, e-mail e pessoalmente.

Ao Professor Dr. Alexandre Nascimento de Almeida, pela colaboração extraclasse sobre a utilização dos métodos quantitativos via Software.

Aos responsáveis pela criação e gestão deste curso de mestrado e demais servidores, colaboradores da UnB/FUP envolvidos no Programa de Pós-Graduação em Gestão Pública (PPGP), pela presteza no atendimento.

A todos os alunos (colegas e amigos) do curso de mestrado, pela vivência e pelas contribuições compartilhadas ao longo do curso; entre eles, a Ione dos Santos Velame, pelo desenvolvimento conjunto de importantes estudos, trabalhos e pelo apoio.

Aos colegas portugueses que nos recepcionaram de maneira muito especial no Instituto Superior de Ciências Sociais e Políticas (ISCSP)/Universidade de Lisboa, onde participamos do Programa de Imersão, experiência que me trouxe importantes conhecimentos para a vida acadêmica, profissional e pessoal.

Ao Reitor e ao Pró-Reitor de Desenvolvimento Institucional, a Diretoria de Desenvolvimento de Recursos Humanos (DDRH) do IFG, que apoiaram e autorizaram esta pesquisa; e aos demais servidores dessas instâncias e da Coordenação de Assistência ao Servidor (CAS), pelo apoio e fornecimento de informações e impressos importantes para a realização deste trabalho. 
Ao Diretor-Geral, do IFG campus Luziânia, Prof. José Carlos Barros Silva, pelo constante apoio, tendo atendido prontamente todas as minhas solicitações vinculadas ao curso de mestrado e profissionais, em função das ausências para estudos.

À equipe de trabalho IFG campus Luziânia lotada na Coordenação de Recursos Humanos e Assistência Social (CRHAS), que atuou intensamente na minha ausência para realizar a crescente demanda de trabalho referente à gestão de pessoas e do Subsistema Integrado de Atenção à Saúde do Servidor (SIASS).

A todos os servidores e servidoras (docentes e técnico-administrativos) do IFG campus Luziânia, dos outros campi e da Reitora, que, de alguma maneira, colaboraram para o desenvolvimento desta pesquisa, com ênfase para os entrevistados, sem os quais esta obra não seria concretizada.

Sem desprezar nenhum outro colaborador, destaco as contribuições de Norma Esther Negrete Calpineiro, Letícia Érica Gonçalves Ribeiro e de Lourenildo Targino Pedrosa, que me acompanharam e apoiaram do início ao final desta caminhada.

A todos os meus familiares, que encararam a minha ausência como algo positivo e importante para nossas vidas; entre eles, a minha esposa Aparecida de Freitas e Silva e filhos Gabriel de Matos Silva, Karina de Matos Silva e Fabrício de Freitas e Silva.

À minha mãe, Irma Lúcia Ferreira Rufino, que sempre apontou a importância de eu continuar estudando.

Aos meus amigos do grupo de canto religioso, que se empenharam para cobrir minhas ausências justificadas pela dedicação ao mestrado.

Enfim, a todas as pessoas que torceram e/ou colaboraram para o desenvolvimento e conclusão desta pesquisa, eu lhes serei grato por toda a vida.

Muito obrigado! 
O SUS é uma conquista e um patrimônio do povo brasileiro. E a população precisa tomar conhecimento das suas lutas, de sua história para melhor compreender a ação dos seus algozes $e$ pretensos coveiros, bem como os interesses espúrios que não ousam explicitar na esfera pública.

(PAIM; TEIXEIRA, 2007, p. 1827) 
SILVA, F. A. C. Análise da utilização do Sistema Único de Saúde por servidores públicos federais que possuem planos privados de saúde. 2016. 87 p. Dissertação (Mestrado Profissional em Gestão Pública) - Programa de Mestrado Profissional em Gestão Pública, Faculdade UnB de Planaltina, Universidade de Brasília, Brasília, 2016.

\section{RESUMO}

Esta pesquisa analisa os principais motivos da procura pelos serviços de saúde disponíveis no Sistema Único de Saúde (SUS) por servidores ativos do Instituto Federal de Goiás (IFG) que possuem planos privados de saúde financiados pelo poder público. Consiste em um estudo exploratório de caráter descritivo com abordagem quantitativa por meio de amostragem não probabilística. O auxílio-saúde, criado para patrocinar planos de saúde para servidores federais foi instituído em função de uma obrigação trabalhista, apontado neste trabalho como sendo um fator que interfere diretamente na equidade e no acesso universal à saúde preconizado pelo SUS. Coletaram-se os dados por meio de um questionário, no qual se empregaram os métodos de análise descritiva e de conteúdo e o Teste do Qui-Quadrado. Constatou-se que a falta de cobertura dos planos de saúde foi apontada como o principal motivo para que os servidores estudados e seus dependentes continuem utilizando o sistema público de saúde em detrimento ao uso dos respectivos planos de saúde. Dessa maneira, conclui-se que o auxílio-saúde não apresenta sinais de diminuição das demandas da saúde pública, mas pelo contrário, associado à renúncia fiscal e ao alto índice de inadimplência do Ressarcimento ao SUS, onera-o ainda mais.

Palavras-chave: Saúde suplementar; Plano privado de saúde; Auxílio-saúde; Renúncia fiscal; Ressarcimento ao SUS. 
SILVA, F. A. C. Analysis of the use of the Unified Health System by federal civil servants who have private health plans. 2016. 87 p. Dissertation (Professional Master in Public Management) - Program of Professional Master in Public Management, Faculty UnB of Planaltina, University of Brasília, Brasília, 2016.

\begin{abstract}
This research analyzes the main reasons of demand by health services available in the Sistema Único de Saúde - SUS (in English, Unified Health System) by active employees of Instituto Federal de Goiás (IFG) that have private health plans financed by the government. It consists of an exploratory study of descriptive character with quantitative approach by means of nonprobabilistic sampling. The aid-health, created to sponsor health plans for federal employees was established due to a labor obligation, pointed in this work as being a factor that interferes directly in equity and in universal access to health care recommended by the SUS. The data were collected through a questionnaire, which employed the methods of descriptive and content analysis and the Chi-Square Test. It was found that the lack of coverage of health plans was pointed out as the main reason for the employees studied and their dependent continue using the Unified Health System in detriment to the use of the respective health plans. This way, it is concluded that the aid-health does not show any signs of decrease of public health demands of, but on the contrary, associated with the waiver of tax and the high rate of default of Reimbursement to the SUS, it burdens it further.
\end{abstract}

Keywords: Supplementary health; Private healthcare plan; Aid-health; Fiscal waiver; Reimbursement to SUS. 


\section{LISTA DE FIGURAS}

Figura 1 - Novo formato de funcionamento do Ressarcimento ao SUS ................................ 32

Figura 2 - Modelos produtivos tradicional e verticalizado. ................................................... 37

Figura 3 - Empresas privadas de saúde que efetuaram doações eleitorais em 2014............... 40 


\section{LISTA DE TABELAS}

Tabela 1 - Perfis dos servidores Técnico-administrativos e Professores do Ensino Básico, Técnico e Tecnológico (EBTT) do IFG que utilizaram o SUS nos últimos seis meses, por Nível de Atenção dos procedimentos realizados, Goiás, 2016.

Tabela 2 - Motivos de os servidores terem recorrido ao SUS nos últimos seis meses em detrimento ao uso dos planos privados de saúde, Goiás, 2016.

Tabela 3 - Estados e Cidades onde os respondentes buscaram o SUS nos últimos seis meses, Goiás, 2016.

Tabela 4 - Procedimentos mais utilizados no SUS pelos respondentes nos últimos seis meses, Goiás, 2016. 61

Tabela 5 - Tempo de espera desde a chegada até a conclusão dos atendimentos recebidos pelos respondentes que utilizaram SUS nos últimos seis meses, Goiás, 2016. 66 


\section{LISTA DE QUADROS}

Quadro 1 - Características dos fatores inerentes ao acesso à saúde......................................47 


\section{LISTA DE ABREVIATURAS E SIGLAS}

ADCSS Administração Central do Sistema de Saúde

AIH Autorização de Internação Hospitalar

AIS Ações Integradas de Saúde

ANS Agência Nacional de Saúde Suplementar

APAC Autorização de Procedimento Ambulatorial

ASPS Ações e Serviços Públicos em Saúde

CAIS Centro Integral de Atenção à Saúde

CAS Coordenação de Assistência ao Servidor

CASSI Caixa de Assistência dos Funcionários do Banco do Brasil

CD Crescimento e Desenvolvimento

CEBES Centro Brasileiro de Estudos de Saúde

CNS Cartão Nacional de Saúde

$8^{\mathrm{a}} \mathrm{CNS} \quad 8^{\mathrm{a}}$ Conferência Nacional de Saúde

CONASP Conselho Consultivo de Administração da Saúde Previdenciária

CRHAS Coordenação de Recursos Humanos e Assistência Social

DATASUS Departamento de Informática do SUS

DDRH Diretoria de Desenvolvimento de Recursos Humanos

DPS Direção Provincial de Saúde

EBTT Ensino Básico, Técnico e Tecnológico

eSIC Sistema Eletrônico do Serviço de Informação ao Cidadão

ECG Eletrocardiograma

EEG Eletroencefalograma

ESF Estratégia Saúde da Família

FNS Fundo Nacional de Saúde

FUP Faculdade UnB de Planaltina

GEAP Grupo Executivo de Assistência Patronal

IBGE Instituto Brasileiro de Geografia e Estatística

IFG Instituto Federal de Educação, Ciência e Tecnologia de Goiás

INAMPS Instituto Nacional de Assistência Médica da Previdência Social

INPS Instituto Nacional de Previdência Social 
IRPF Imposto de Renda de Pessoas Físicas

IRPJ Imposto de Renda de Pessoa Jurídica

ISCSP Instituto Superior de Ciências Sociais e Políticas

MCDT Meios Complementares de Diagnóstico e Terapêutica

MEC Ministério da Educação

MS Ministério da Saúde

MPOG Ministério do Planejamento, Orçamento e Gestão

OPS Operadoras de Planos de Saúde

PIB Produto Interno Bruto

PNAD Pesquisa Nacional por Amostra de Domicílios

PNAN Política Nacional de Alimentação e Nutrição

PNI Programa Nacional de Imunizações

PPGP Programa de Pós-Graduação em Gestão Pública

PRODI Pró-Reitoria de Desenvolvimento Institucional

SIASS Subsistema Integrado de Atenção à Saúde do Servidor

SERPRO Serviço Federal de Processamento de Dados

SIH Sistema de Informação Hospitalar

SIH/SUS Sistema de Informações Hospitalares do SUS

SIPEC Sistema de Pessoal Civil da Administração Federal

SNS Serviço Nacional de SaúdeX

SPSS Statistical Package for the Social Sciences

SRH Secretaria de Recursos Humanos

STF Supremo Tribunal Federal

SUDS Sistema Unificado e Descentralizado de Saúde

SUS Sistema Único de Saúde

TCLE Termo de Consentimento Livre e Esclarecido

UnB Universidade de Brasília

UNIMED Cooperativa de Trabalho Médico

UPA Unidades de Pronto-Atendimento 


\section{SUMÁRIO}

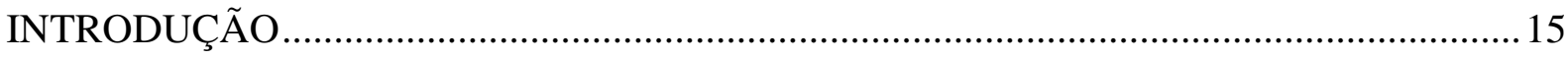

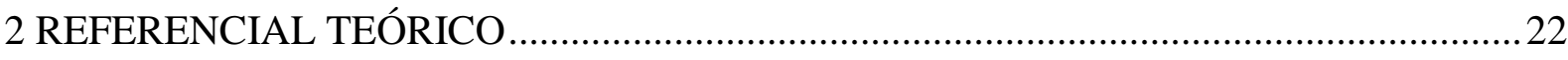

2.1 Sistema Único de Saúde: origem, avanços e limitações .................................... 22

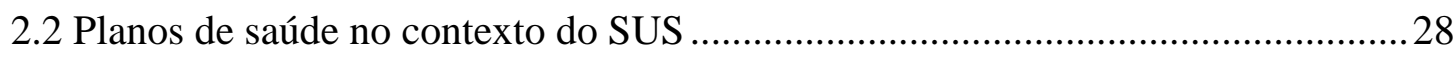

2.3 Ressarcimento ao Sistema Único de Saúde pelas Operadoras ............................... 30

2.4 Repercussões sobre a Cobertura Duplicada em Saúde ........................................33

2.5 Benefícios Fiscais destinados ao Setor Privado de Saúde .................................... 35

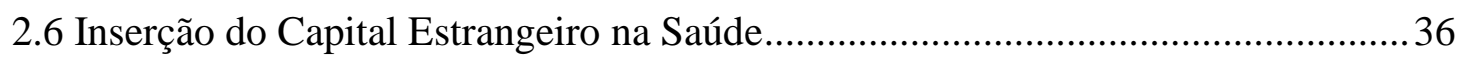

2.7 Interpretação do conceito de Direito à Saúde ......................................................4 44

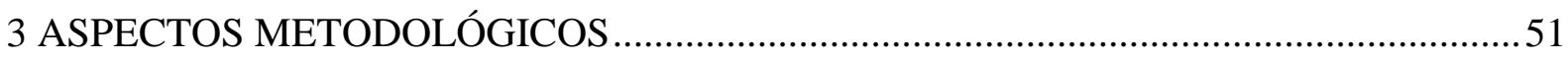

3.1 Tipo de estudo e Delineamento.................................................................... 51

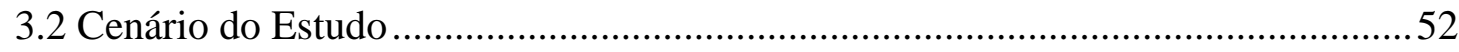

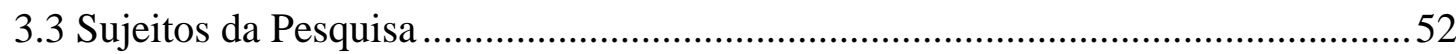

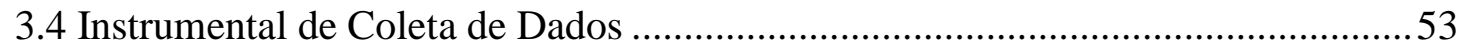

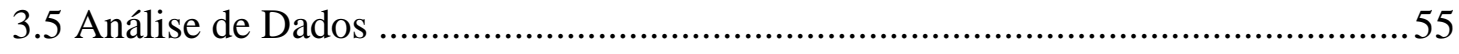

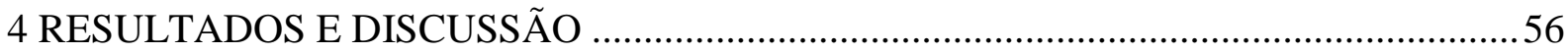

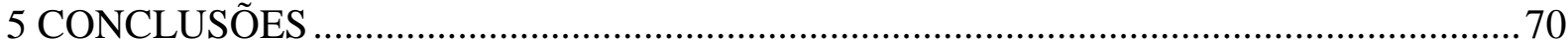

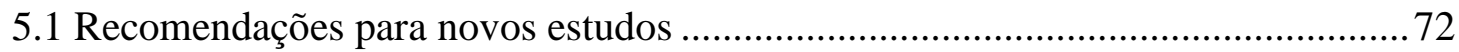

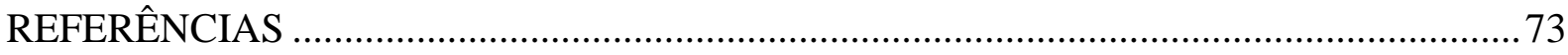

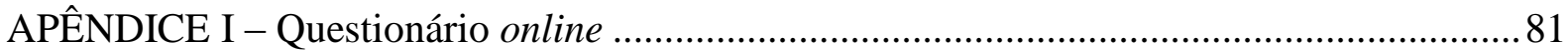




\section{INTRODUÇÃO}

No Brasil, o atual sistema de saúde emergiu de um acordo entre conservadores e progressistas que resultou na coexistência dos setores privado e público de saúde. Assim, a Carta Constitucional de 1988 assegurou a saúde pública em seus artigos 196 a 200; em contrapartida, garantiu-se, no artigo 199, o livre exercício da iniciativa privada (CARVALHO, 2013). Essa criação do Estado ensejou a instituição da assistência à saúde suplementar, ou auxílio-saúde, destinada aos servidores públicos federais está prevista na Lei 8.112/90, em seu artigo 230, o qual dispõe que esse auxílio é financeiro e voltado para o servidor ativo, inativo e aos seus dependentes legais (BRASIL, 1990a).

Para cumprir essa obrigação trabalhista, o Ministério do Planejamento, Orçamento e Gestão (MPOG), por meio da Secretaria de Recursos Humanos (SRH), instituiu a Portaria Normativa $\mathrm{N}^{\mathrm{0}} 5$, em 11 de outubro de 2010, estabelecendo orientações aos órgãos e entidades do Sistema de Pessoal Civil da Administração Federal (SIPEC), responsável pela assistência à saúde suplementar não apenas dos servidores ativos, inativos, seus dependentes e pensionistas, mas também dos ocupantes de cargos comissionados, de natureza especial, bem como aos empregados públicos, inseridos na Administração Pública Federal direta, nas autarquias e nas fundações.

Dessa forma, o servidor que comprovar ser portador de plano de saúde receberá mensalmente um auxílio-saúde de caráter indenizatório geralmente especificado no contracheque como "Per Capita Saúde Suplementar" (BRASIL, 2010), não havendo prazo estipulado para o ajuste ${ }^{1}$ dos valores do auxílio apresentado. Além disso, os custos adicionais com o plano de saúde serão de responsabilidade exclusiva do servidor.

\footnotetext{
${ }^{1}$ Em 14 de janeiro de 2016, o Ministério do Planejamento, Orçamento e Gestão publicou a Portaria Normativa $n^{\circ}$ 8 de 13/01/2016, ajustando os valores referentes à participação da União no custeio da assistência à saúde
} 
De acordo com o Ministério do Planejamento, a referida normativa assegura que o auxílio-saúde, também conhecido como assistência à saúde suplementar ou ressarcimento, será pago exclusivamente aos servidores que possuem planos privados de saúde, ou seja, sem comprovação documental de adesão e pagamento do plano de saúde, o servidor não fará jus ao auxílio mencionado. Todavia, existem três formas de comprovação de pagamento do plano de saúde, quais sejam: Débito automático em conta corrente; Autogestão; e Comprovação documental de pagamento.

No caso do Débito automático em conta corrente, a operadora de plano de saúde conveniada envia mensalmente um relatório financeiro ao setor de Recursos Humanos das instituições públicas contendo os nomes dos servidores que efetuaram os pagamentos dos respectivos planos de saúde.

Na Autogestão, o Ministério do Planejamento autoriza a empresa conveniada a gerenciar a cobrança do plano de saúde por meio de consignação em folha de pagamento. Nesse formato de cobrança, uma empresa particular passa a ter acesso ao contracheque do servidor federal para realizar o desconto em folha referente ao plano de saúde. Essa modalidade de cobrança, praticada, por exemplo, pelo Grupo Executivo de Assistência Patronal (GEAP) - Autogestão em Saúde, não exige comprovação de pagamento no setor de Recursos Humanos.

$\mathrm{Na}$ Comprovação documental de pagamento, legalmente só haverá ressarcimento/auxílio-saúde após a confirmação de pagamento, portanto, os servidores deverão apresentar os boletos e comprovantes de pagamento de qualquer operadora de plano de saúde credenciada pela Agência Nacional de Saúde Suplementar (ANS) impreterivelmente até o $5^{\circ}$ dia útil de cada mês no setor de Recursos Humanos. Caso contrário, o auxílio-saúde não será lançado. Vale destacar que o valor per capita do auxílio-saúde será menor ou igual passaram a receber um valor per capita de entre $\mathbf{R} \$ \mathbf{1 0 1 , 5 6}$ a $\mathbf{R} \mathbf{2 0 5 , 6 3}$ (BRASIL, 2016a). 
ao valor do plano de saúde, evitando que o servidor receba recursos públicos superiores ao valor do plano de saúde contratado (BRASIL, 2010).

Nesse contexto, Ocké-Reis (2010) assinala que o servidor público que possui plano de saúde e utiliza o SUS ocupa uma posição privilegiada em comparação aos cidadãos que dependem exclusivamente do sistema público de saúde. Com isto, o Estado gasta duplamente quando fornece recursos financeiros para custear planos de saúde para servidores que recorrem aos serviços de saúde do SUS em detrimento ao uso do plano de saúde contratado.

Para diminuir os custos em caso de utilização do setor público de saúde por consumidores de planos de saúde, cabe à Agência de Saúde Suplementar emitir cobrança financeira às Operadoras de Planos Privados de Saúde (OPS), referente aos atendimentos de seus respectivos clientes no Sistema Único de Saúde. Isso significa que o portador de plano de saúde que utiliza a rede pública de saúde deverá ter o valor de seu atendimento repassado pela operadora ao Estado. Este ato é conhecido como Ressarcimento ao SUS (BRASIL, 2000a).

Em 2014, a ANS apresentou um mapeamento inédito sobre o Ressarcimento ao SUS, com o intuito de levar as operadoras de planos privados de saúde ao desenvolvimento de melhores práticas, trazendo ainda novos recursos regulatórios. $\mathrm{Na}$ atual situação, esse ressarcimento engloba internações hospitalares e demais procedimentos realizados pelo SUS em favor de usuários de planos privados de saúde devidamente registrados por Autorização de Internação Hospitalar (AIH) (BRASIL, 2014a).

No Brasil, existem 1.510 operadoras de planos privados de saúde que recebem cobrança da ANS, sendo que 76\% delas possuem débitos com o SUS. Dessas instituições, 1.151 não pagaram integralmente suas dívidas aos cofres públicos. Além disso, constatou-se que o índice de inadimplência de $26 \%$ é gerado pelas empresas que não pagaram e não optaram pelo parcelamento de suas pendências financeiras junto ao SUS. Outra preocupação 
diz respeito a $45 \%$ das empresas devedoras que deixaram de existir. Os $24 \%$ das operadoras citadas que não possuem pendências financeiras com o Estado não são suficientes para atribuir eficiência ao atual mecanismo de cobrança. Pelo contrário, isto comprova a ineficiência do sistema de cobrança adotado pela ANS, o qual precisa ser aprimorado (CRUZ, 2015).

A coexistência dos sistemas público e privado de saúde resulta em ampliação das iniquidades: enquanto os portadores de planos privados de saúde transitam nas duas instâncias, aqueles que se situam em condições de extrema pobreza e/ou necessidades diversas contam apenas com a rede pública de saúde. Assim, o gasto público em saúde age de forma contrária aos preceitos legais que visam justiça social, por isso, acaba contribuindo com a lógica discriminatória do capital (OCKÉ-REIS, 2010).

Mesmo com o mercado de saúde operando de forma crescente em nosso país, Scheffer (2015a) ressalta que, na prática, o SUS suporta a carga demandada pela rede pública e pelas operadoras de planos de saúde. Portanto, essa proximidade do Estado com a rede privada transforma o cidadão com direito fundamental e acesso livre à saúde em cliente com obrigação de pagar pelo uso dos recursos da saúde privada. Isso resulta em afastamento da possibilidade de universalização do acesso à saúde, pois depende não somente de uma gestão qualificada, mas também de recursos financeiros cada vez mais escassos.

A universalização da saúde surge "como parte intrínseca à luta pela democracia, assim como a institucionalização da universalização da democracia aparece como condição para garantia da saúde como direito de cidadania”, segundo Fleury (2009, p. 157). Contudo, o confronto entre saúde pública e privada gera obstáculos para a ampliação do acesso e utilização da saúde pública no país.

Segundo Ocké-Reis (2010), ao invés de avaliar o nível de gasto público em saúde com foco no fortalecimento do SUS, o Estado se torna um incentivador do uso do setor 
privado de saúde. Além disso, perde na arrecadação fiscal empresarial e na restituição do Imposto de Renda de Pessoa Física, e, assim, a universalização do acesso à saúde pública fica cada vez mais distante.

Para confirmar o que foi dito, Mendes e Weiller (2015, p. 503) acrescentam que, nos últimos anos, a Renúncia Fiscal ${ }^{2}$ também conhecida como gasto tributário por parte do Estado vem ganhando grandes proporções, alcançando “o patamar de R\$ 19,98 bilhões em 2012. Tal recurso, se destinado ao SUS, contribuiria significativamente para enfrentar o subfinanciamento desse sistema". O autor acredita que, em decorrência da ausência de um controle mais rigoroso dos subsídios ofertados ao setor privado de saúde, o Estado gera ainda mais desigualdades relacionadas com o acesso e a utilização do sistema público de saúde.

Na mesma linha, Ocké-Reis (2015) afirma que o gasto público em saúde é agravado por falhas de gestão, mas principalmente pela renúncia fiscal, incluindo-se, ainda, a inadimplência do Ressarcimento ao SUS. Com isto, o paradoxo estatal consiste em, de um lado, defender um sistema de saúde universal e gratuito, focalizado na equidade; de outro, em legislar em favor dos interesses do mercado de planos de saúde, bem como pelo financiamento parcial direto ou indireto da assistência à saúde suplementar guiada exclusivamente pelo lucro.

A questão-problema desta pesquisa pretende identificar os principais motivos da procura pelo SUS e os procedimentos que os servidores ativos do Instituto Federal de Educação, Ciência e Tecnologia de Goiás (IFG) buscam e realizam na rede pública de saúde em detrimento ao uso do plano privado de saúde contratado com recursos públicos.

Destaca-se que a importância desta pesquisa reside em evidenciar o que Bahia (2013) estabelece como a dualidade de subsistemas: um, para indivíduos pobres; e outro,

\footnotetext{
${ }^{2}$ As renúncias fiscais (gastos tributários) se apresentam como engrenagens que ampliam o poder das instituições privadas no setor de saúde, prejudicando o financiamento do Sistema Único de Saúde (MENDES; WEILLER, 2015, p. 491).
} 
financiado com dinheiro público, para atender os mais abastados. Na declaração dessa autora, há necessidade de valorizar pesquisas envolvendo planos e seguros privados de saúde, considerando-se que a falta de equidade - a qual permite acesso duplicado do portador de plano de saúde que utiliza o SUS - acaba gerando mais iniquidades.

Acrescenta-se ainda que no ano de 2015, o gasto público da União com planos privados de saúde para os servidores ativos do IFG alcançou o patamar de R $\$$ 3.690.553,64 (milhões). Destaca-se que apenas 53,72\% do valor apresentado seria suficiente, por exemplo, para manter anualmente em funcionamento um dos campi da referida instituição inaugurado no último triênio (BRASIL, 2016d).

Embora o gasto da União com planos de saúde para servidores federais tenha previsão legal, isso envolve o princípio da equidade e interfere diretamente no gasto público em saúde, podendo afetar todos os usuários do SUS. Por isso, Fleury (2009) propõe que a população deva conhecer os motivos pelos quais o Estado decidiu patrocinar planos privados de saúde para servidores federais. Esta proposição reforça ainda mais que este estudo diz respeito a uma questão atual e relevante para o desenvolvimento de outras pesquisas no campo da administração pública, assim como na área de saúde. 


\section{Objetivo geral}

Analisar os principais motivos da procura pelos serviços públicos de saúde do SUS por servidores ativos do IFG que possuem planos privados de saúde financiados com recursos do Estado.

\section{Objetivos específicos}

- Traçar o perfil dos servidores ativos do IFG que recebem auxílio-saúde e utilizaram o SUS nos últimos seis meses;

- Identificar os principais motivos da procura pelos serviços públicos de saúde do SUS nos últimos seis meses por servidores ativos do IFG que recebem auxílio-saúde;

- Mapear os procedimentos do SUS utilizados por servidores ativos do IFG que recebem auxílio-saúde e utilizaram o SUS nos últimos seis meses.

A dissertação está dividida em cinco capítulos, a saber: o primeiro capítulo é introdutório e traz o problema do estudo, objetivos geral e específicos. O segundo capítulo apresenta o Referencial Teórico que aborda sobre o Sistema Único de Saúde: origem, avanços, limitações e seus desafios, assim como os principais aspectos inerentes aos planos privados de saúde no contexto da saúde pública. No terceiro capítulo, discorre-se sobre os aspectos metodológicos, contendo informações sobre o tipo de estudo e delineamento, local de realização e sujeitos da pesquisa, bem como o instrumental de coleta e análise de dados. $\mathrm{O}$ quarto capítulo diz respeito aos resultados e discussão, e traz, de forma lógica e organizada, os principais achados da pesquisa. Por fim, o quinto capítulo congrega as conclusões e recomendações para novos estudos, acrescendo-se as referências bibliográficas e o apêndice. 


\section{REFERENCIAL TEÓRICO}

Conforme a argumentação de Fleury (2009), o Movimento pela Reforma Sanitária foi instituído em 1979, por meio do Centro Brasileiro de Estudos de Saúde (CEBES), com base na crise do saber e da prática médica focalizada na criação de um sistema público de saúde, em detrimento da lógica de mercantilização da saúde. Os projetos da Reforma Sanitária buscavam reconhecimento político e institucional; ampliação da consciência sanitária entre usuários e profissionais da área de saúde; definição da saúde como bem público mediante legalização que possibilitasse a universalização e a equidade. O sistema de saúde mencionado seria construído para funcionar de forma descentralizada nas três esferas de governo, em unidades hierarquizadas com permissão para a participação popular em todas as instâncias.

\subsection{Sistema Único de Saúde: origem, avanços e limitações}

Até o final dos anos 1980, as políticas de saúde brasileiras vinculavam-se ao Instituto Nacional de Previdência Social (INPS) e ainda não alcançavam toda a população. Os mais necessitados eram excluídos, pois o acesso à saúde dependia de ter a carteirinha do INPS ou recursos financeiros para custear os serviços de saúde; caso contrário, os desvalidos contavam apenas com a bondade alheia (DOBASHI; BRÊTAS JR.; SILVA, 2010). Tendo em vista que apenas os trabalhadores, assim como aqueles que podiam pagar pelos serviços de saúde, estavam amparados, a universalização da saúde pretendia abarcar toda a população.

O início da década de 1980 ficou marcado pelas manifestações contra o sistema de saúde governamental; por isso, democratizar e descentralizar os serviços de saúde seria uma alternativa acertada. Simultaneamente se agravou a crise na Previdência Social, mais precisamente em 1981. Esse fato originou o lançamento do "pacote da previdência", que 
diminuiu os benefícios dos aposentados e elevou as alíquotas de contribuição, bem como passou a interferir menos na assistência médica da Previdência Social. Esse ambiente possibilitou a criação do Conselho Consultivo de Administração da Saúde Previdenciária (CONASP), por meio do Decreto nº 86.329/1981, da Presidência da República, que buscava, entre outros objetivos, efetuar a Reorientação da Assistência à Saúde na Previdência Social. Em 1982, os oprimidos secretários estaduais de saúde se uniram em prol da urgência de criar meios para pressionar o Governo Federal durante as negociações e demais discussões sobre políticas públicas. Tendo como principal meta transformar os discursos em torno das políticas públicas uma realidade prática, os secretários mencionados instituíram o Conselho Nacional de Secretários de Saúde (BRASIL, 2013). Cabe acrescentar que a crise da previdência

provocou que se levasse a cabo uma associação mais forte entre o Inamps e os serviços públicos de saúde. Nasce aí o que se denominou Ações Integradas de Saúde (AIS). O cerne: parceria da previdência com a saúde pública municipal e estadual; prestação de cuidados, principalmente primários ambulatoriais; transferência de recursos da previdência para que fossem realizadas essas ações pelos Estados e municípios (CARVALHO, 2013, p. 9).

Essas Ações Integradas de Saúde apontadas como pilares do CONASP foram implantadas no ano de 1983, sendo parte do programa de atenção médica urbana (BRASIL, 2013).

De acordo com Santos e Amarante (2010), em 1986, as AIS contavam com a participação de 2.500 municípios. Contudo, foi a $8^{\mathrm{a}}$ Conferência Nacional de Saúde ( $\left.8^{\mathrm{a}} \mathrm{CNS}\right)$, realizada no Distrito Federal em 1986 - quando aproximadamente cinco mil delegados se juntaram com população para ratificar a saúde como um direito - que se destacou como um marco histórico na construção do Sistema Unificado e Descentralizado de Saúde (SUDS). Criado em 1987, o SUDS resultou do aprimoramento das AIS. Vale relatar que a $8^{\text {a }}$ CNS serviu ainda para consolidar o Movimento Sanitário, pois, a partir desse significativo acontecimento, muitas universidades passaram a dar mais atenção aos departamentos de medicina preventiva. 
Após um ano, constatou-se, no relato de Teixeira (2011), que o referido sistema de saúde foi assegurado como uma política estatal promulgada em nossa Constituição Federal de 1988, reforçando a ideia de que a saúde deve ser vista como uma obrigação do poder público e um direito do cidadão. Originário de um longo processo, diversas forças sociais fortaleceram o Movimento Sanitarista, que visava, entre outras questões, garantir ao povo melhores condições de saúde, contrapondo-se à perspectiva de redução do papel do Estado. $\mathrm{O}$ referido reconhecimento da saúde como direito só se tornou

possível após longa luta política e graças à atuação do Movimento pela Reforma Sanitária. A implantação de um sistema de saúde universal no Brasil teve início em um contexto político e econômico desfavorável, que promovia a ideologia neoliberal, perspectiva essa reforçada por organizações internacionais contrárias ao financiamento público de sistemas de saúde nacionais e universais ou que defendiam etapas intermediárias para atingi-los (PAIM et al., 2012, p. 27).

Contudo, Carvalho (2013) relata que, em 1991, o SUDS foi substituído pelo SUS. Esse novo sistema de saúde congrega ações e serviços de saúde, públicos e gratuitos, sendo organizado em redes regionalizadas e hierarquizadas com atuação em todo o país. Essa rede hierarquizada incorpora os níveis de Atenção Básica, Média Complexidade, assim como a Alta Complexidade.

Em cada ente federado deverá haver um gestor responsável pela direção do SUS, ou seja: na instância federal, esse papel será desempenhado pelo Presidente da República e pelo Ministro da Saúde; no Estado, cabe ao Governador, assim como ao Secretário Estadual de Saúde; no âmbito municipal, essa tarefa fica a cargo do Prefeito e do Secretário Municipal de Saúde (CARVALHO, 2013).

Foi na $13^{a}$ Conferência Nacional de Saúde que a expressão Políticas de Estado surgiu como tema central, para evidenciar 
um compromisso e uma obrigação permanentes que não devem se submeter a interesses conjunturais de governos, partidos e corporações. Os governos responsáveis pela saúde no regime presidencialista brasileiro, embora concentrem-se no Executivo (federal, estadual e municipal), devem interagir com o Legislativo e serem fiscalizados pelo Judiciário e Ministério Público (PAIM e TEIXEIRA, 2007, p. 1820, grifos nossos).

Segundo Paim (2009a), o Movimento Sanitarista foi decisivo na criação do Sistema Único de Saúde, que representa uma das maiores vitórias da pulação alcançada por meio da Constituição Federal vigente. O Ministério da Saúde (MS) esclarece que o SUS foi constituído no mês de outubro de 1988, no entanto, foi necessário ainda criar outras leis para regulamentar esta política de Estado (BRASIL, 2000b).

Logo, fez-se necessário instituir a Lei 8.080/90, dispondo sobre as condições para a promoção, proteção e recuperação da saúde, a organização e o funcionamento dos serviços correspondentes, e enfatizando que a saúde precisa ser encarada como um direito essencial do indivíduo. Segundo tal lei, o Estado deve ofertar as devidas condições de acesso universal e igualitário aos serviços e ações de saúde (BRASIL, 1990b). Essa lei trouxe como destaques: a garantia de participação popular, o direito à informação, e as transferências intergovernamentais de recursos financeiros. Todos esses itens são de extrema importância no campo da saúde pública.

Após a criação da Lei Complementar $n^{\circ} 141$ em 2012, estabeleceram-se os percentuais destinados ao investimento mínimo em Ações e Serviços Públicos em Saúde (ASPS). Conforme prevê a legislação, caberá à União aplicar, em cada ano, um montante equivalente ao que foi empenhado no último exercício financeiro com acréscimo mínimo correspondente à variação nominal do Produto Interno Bruto (PIB) do ano anterior. Essa lei define a aplicação mínima, nos municípios e Distrito Federal, de 15\% (quinze por cento) da arrecadação dos impostos, com dedução das parcelas repassadas aos respectivos Municípios. Já aos Estados, cabe a aplicação de $12 \%$ (doze por cento) da arrecadação dos impostos. Os recursos financeiros destinados à saúde pública são repassados por meio do fundo de saúde 
estabelecido em cada esfera de governo, tais como: Fundo Nacional de Saúde, Fundo Estadual de Saúde, e Fundo Municipal de Saúde (BRASIL, 2012).

O SUS foi criado há 27 anos e naturalmente sofreu alterações. Entre elas, uma fundamental modificação no financiamento, relacionada com o

custeio das ações e serviços de saúde, é a alocação dos recursos federais em cinco
blocos. As bases de cálculo que formam cada Bloco e os montantes financeiros
destinados para os estados, municípios e Distrito Federal serão compostos por
memórias de cálculo, para fins de histórico e monitoramento. Dessa forma, estados
e municípios terão maior autonomia para alocação dos recursos de acordo com as
metas e prioridades estabelecidas nos planos de saúde. Os blocos de financiamento
federal são: Atenção básica, Atençãa de média e alta complexidade, Vigilância
em Saúde, Assistência Farmacêutica estão do SUS (BRASIL, 2007, p. 128, grifos
nossos).

Na compreensão de Fleury (2009), apesar do longo tempo percorrido desde a criação do SUS, ainda não foi possível garantir uma fonte de financiamento condizente com o gasto público necessário para o funcionamento desse sistema. Entretanto, para resolver os problemas financeiros, o Brasil precisaria aumentar o investimento em saúde, passando de 3,6\% para, no mínimo, 7\% do PIB. Além disso, a renúncia fiscal deveria ser eliminada, bem como os repasses de recursos públicos ao setor privado de saúde. Com isto, anualmente o SUS poderia contar com aproximadamente 20 bilhões de reais (CAMPOS, 2013).

No pensamento de Teixeira (2011), o setor público é obrigado a dispor de um enorme volume de recursos financeiros para realizar investimentos na estrutura do sistema, construção e reforma dos centros de saúde, aquisição de equipamentos, Recursos Humanos, entre outros, com foco na garantia da universalização do acesso.

Sobre o subfinanciamento do SUS, convém acrescentar que 
para enfrentar essa insuficiência de recursos públicos para a saúde dos brasileiros, deveríamos nos preocupar com a persistência dos incentivos fiscais ao setor privado da saúde, o que se traduz no subsídio implícito nas deduções do Imposto de Renda das despesas com Planos Privados de Saúde e/ou com despesas particulares com médicos, hospitais e exames. O que vem à tona é um direcionamento da saúde pública para uma mercantilização, de direito social a produto, provocando um ocultamento enquanto política social, que vise à universalidade, à igualdade e à equidade (MENDES; WEILLER, 2015, p. 503).

Além disso, o Estado deve redefinir as atribuições inerentes à saúde pública e principalmente no que diz respeito às operadoras de planos privados de saúde, pois a consolidação do SUS depende de mobilização política para reestruturar o financiamento da saúde (OCKÉ-REIS, 2015).

Vale destacar que existem outros problemas que dificultam o funcionamento da rede pública de saúde, posto que "o processo da Reforma Sanitária, institucionalizado no SUS, descreve sua história em meio a diversos impasses, tendo na falta de recursos um dos maiores dilemas a ser enfrentado" (DA SILVA; ROTTA, 2012, p. 11, grifo nosso).

Com posicionamento contrário, Guerra (2013) afirma que a falta de recursos não é o problema mais grave do SUS, mas sim a gestão ineficiente desses recursos que provoca sérios danos ao setor público de saúde. No entanto, Bahia (2013) assegura que, no SUS, o principal entrave é "político", pois o aspecto distributivo envolve tanto a parte de financiamento do SUS quanto a divisão de poder. Assim sendo, o problema político influencia diretamente sobre a decisão da existência de dois subsistemas de saúde no Brasil: um subsistema pobre para atender exclusivamente aos indivíduos de baixa renda; e outro financiado com o dinheiro público, para atender às classes sociais mais abastadas.

Notou-se que o SUS ainda não consegue garantir padrões elevados de qualidade. E os maiores desafios que se apresentam são realmente políticos, "pois supõem a garantia do financiamento do subsistema público, a redefiniçãa da articulação público-privada e a redução das desigualdades de renda, poder e saúde” (PAIM, 2013, p. 7).

Embora tenha havido avanços na saúde pública, Fleury (2009) aponta que, trinta anos depois, ainda persistem os problemas de administração, gestão de pessoas, Recursos 
Humanos, acesso e qualidade dos serviços, financiamento e o embate entre a saúde pública e privada. Além disso, a autora destaca que o SUS ainda não alcançou completamente o modelo igualitário, portanto, as questões inerentes a qualquer problema do sistema público de saúde devem considerar o princípio da equidade. Além disso, a autora aponta a importância de identificar os verdadeiros motivos pelos quais o Estado financia planos de saúde para servidores públicos, pois esta prática compromete a democracia e gera cada vez mais iniquidades.

\title{
2.2 Planos de saúde no contexto do SUS
}

A Lei 9.656, de 3 de junho de 1998, dispõe acerca dos planos e seguros privados de assistência à saúde em nosso país. Em seu artigo primeiro, inciso I, determina que o Plano Privado de Assistência à Saúde, deverá realizar

\begin{abstract}
a prestação continuada de serviços ou cobertura de custos assistenciais a preço pré ou pós estabelecido, por prazo indeterminado, com a finalidade de garantir, sem limite financeiro, a assistência à saúde, pela faculdade de acesso e atendimento por profissionais ou serviços de saúde, livremente escolhidos, integrantes ou não de rede credenciada, contratada ou referenciada, visando a assistência médica, hospitalar e odontológica, a ser paga integral ou parcialmente às expensas da operadora contratada, mediante reembolso ou pagamento direto ao prestador, por conta e ordem do consumidor (BRASIL, 1998, grifos nossos).
\end{abstract}

No intuito de regular a saúde no setor privado, foi criada a Agência Nacional de Saúde Suplementar, por meio da Lei no 9.961, de 28 de janeiro de 2000, que é uma "autarquia sob o regime especial, vinculada ao Ministério da Saúde, como órgão de regulação, normatização, controle e fiscalização das atividades que garantam a assistência suplementar à saúde". Além disso, vale sublinhar que 
a ANS terá por finalidade institucional promover a defesa do interesse público na assistência suplementar à saúde, regulando as operadoras setoriais, inclusive quanto às suas relações com prestadores e consumidores, contribuindo para o desenvolvimento das ações de saúde no País. Compete à ANS: propor políticas gerais ao Conselho Nacional de Saúde Suplementar - CONSU para a regulação do setor de saúde suplementar; estabelecer as características gerais dos instrumentos contratuais utilizados na atividade das operadoras; estabelecer normas para ressarcimento ao Sistema Único de Saúde; estabelecer normas, rotinas e procedimentos para concessão, manutenção e cancelamento de registro dos produtos das operadoras de planos privados de assistência à saúde; fiscalizar as atividades das operadoras de planos privados de assistência à saúde e zelar pelo cumprimento das normas atinentes ao seu funcionamento (BRASIL, 2000a, grifos nossos).

Essa lei tem sua importância sobre os aspectos financeiros no que diz respeito aos indivíduos que possuem planos privados de saúde e, esporadicamente, recorrem aos serviços/atendimentos do SUS.

Contudo, na visão de Ocké-Reis (2015), o subfinanciamento do SUS se agrava na medida em que falta rigor no processo regulatório das operadoras de planos de saúde por parte da ANS, portanto, os portadores de planos privados de saúde utilizam a rede pública de saúde para: vacinação, urgências e emergências, transplantes, hemodiálise, tratamento de doenças crônicas e demais serviços de alto custo. A cobertura vacinal brasileira é realizada por meio do Programa Nacional de Imunizações (PNI), que foi criado em 1973, e consolidou-se ao longo do tempo, obtendo reconhecimento internacional (BRASIL, 2016b). Segundo Paim et al. (2012), o PNI está entre os mais exitosos programas da área de saúde pública, principalmente por sua ampla cobertura e gratuidade. Além disso, os autores destacam que o Brasil é considerado autossuficiente na fabricação de vacinas.

Acrescenta-se, ainda, que o Sistema Único de Saúde também é responsável pela Política Nacional de Alimentação e Nutrição (PNAN), aprovada no ano de 1999, a qual “integra os esforços do Estado Brasileiro que, por meio de um conjunto de políticas públicas”, tem como objetivo melhorar a alimentação, assim como a nutrição e saúde do povo brasileiro (BRASIL, 2013, p. 6). 
Se, direta ou indiretamente, todos utilizam o SUS, é preciso refletir se o sistema público não seria ainda melhor caso não existisse o setor privado de saúde. Contudo, cabe ressaltar ainda que,

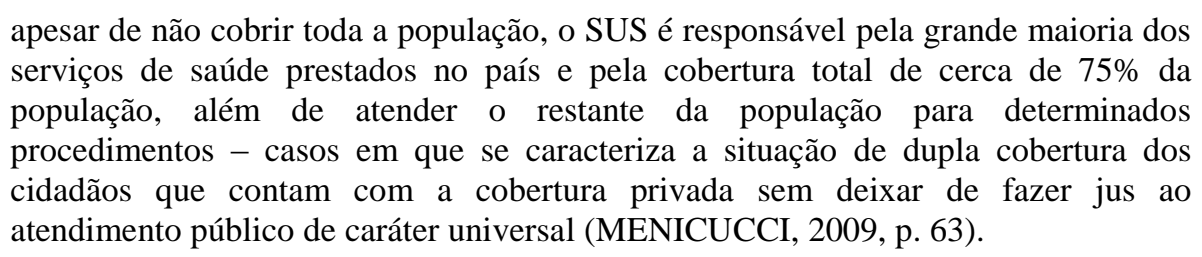

O Instituto de Estudos de Saúde Suplementar (2010) declara que o direito à saúde é constitucional, garantido a toda a população. Por isso, o indivíduo possuidor de plano privado de saúde pode utilizar paralelamente os serviços de saúde do SUS.

\subsection{Ressarcimento ao Sistema Único de Saúde pelas Operadoras}

Após a criação da Lei 9.656/98, todas as operadoras de planos privados de saúde são obrigadas a efetuar o Ressarcimento ao SUS quando seus respectivos beneficiários fizerem uso desse sistema público de saúde. Dessa maneira, esse instrumento pode ser classificado como um dever "legal das operadoras de planos privados de assistência à saúde de restituir as despesas do Sistema Único de Saúde no eventual atendimento de seus beneficiários que estejam cobertos pelos respectivos planos” (BRASIL, 1998).

No pensamento de Ocké-Reis (2010), é de responsabilidade da rede pública de saúde cumprir o princípio da equidade para garantir o acesso à saúde sobretudo dos indivíduos mais vulneráveis; todavia, o Estado não deve estimular o comércio excludente de planos privados de saúde que vise exclusivamente lucros extraordinários. Portanto, a administração pública deve proibir o setor privado de saúde de: usar os leitos públicos; apropriar dos hospitais universitários; não cumprir as regras do ressarcimento, bem como evitar a renúncia arrecadatória. 
Acrescenta-se, ainda, que ao longo do tempo, grande parte dos ressarcimentos não foi efetuada pelas operadoras. De acordo com a ANS, no período de 2000 a 2014, o Ressarcimento ao SUS alcançou o patamar de R\$ 335,74 milhões, contudo, no mesmo período entrou para dívida ativa a cifra de $\mathrm{R} \$ 189,64$ milhões, correspondentes a 56,48\% do total recebido, fato que comprova um prejuízo de mais da metade do que a ANS conseguiu arrecadar das operadoras de planos de saúde nesse período (BRASIL, 2014b). A fim de atenuar a inadimplência das operadoras, a sociedade deve pressionar essa agência para que haja melhorias no processo de cobrança.

Verificou-se que o número de operadoras de planos de saúde inscritas na dívida ativa cresceu de forma acelerada nos últimos sete anos, tendo em vista que no ano de 2008 esses débitos representaram 3,43 milhões, saltando para 189,64 milhões no ano de 2014. Nesse período, o fator inadimplência do Ressarcimento ao SUS cresceu extraordinariamente, totalizando R\$262,84 milhões (BRASIL, 2014b). Ou seja, além dos benefícios fiscais, as operadoras de planos de saúde lucram com o não pagamento das despesas de seus clientes quando utilizam a rede pública de saúde.

Contudo, segundo Brasil (2014a), para melhorar esse precário serviço de cobrança, desde janeiro de 2015, a Agência Nacional de Saúde Complementar conta com as seguintes inovações:

- Software Cadsus Stand Alone - ferramenta informacional que tem a missão de tornar o processo de emissão do Cartão Nacional de Saúde (CNS) mais veloz;

- Sistema eletrônico - possibilita que as operadoras solicitem impugnação e recursos à ANS exclusivamente por meio digital, visando à rapidez e diminuição dos custos; 
- Identificação padronizada e o sistema Comprova - cada operadora deverá ofertar seus dados institucionais e cadastrais de seus clientes. Tais informações serão registradas em um banco de dados, onde o usuário poderá também alterar seus próprios dados no sistema Comprova, disponibilizado pela ANS a partir de 6 de janeiro de 2015.

Por meio da identificação padronizada, os consumidores de planos privados de saúde poderão consultar eletronicamente a situação da operadora na ANS, entre outros (BRASIL, 2014a). A figura abaixo demonstra com clareza o novo modelo de Ressarcimento ao SUS.

Figura 1 - Novo formato de funcionamento do Ressarcimento ao SUS.

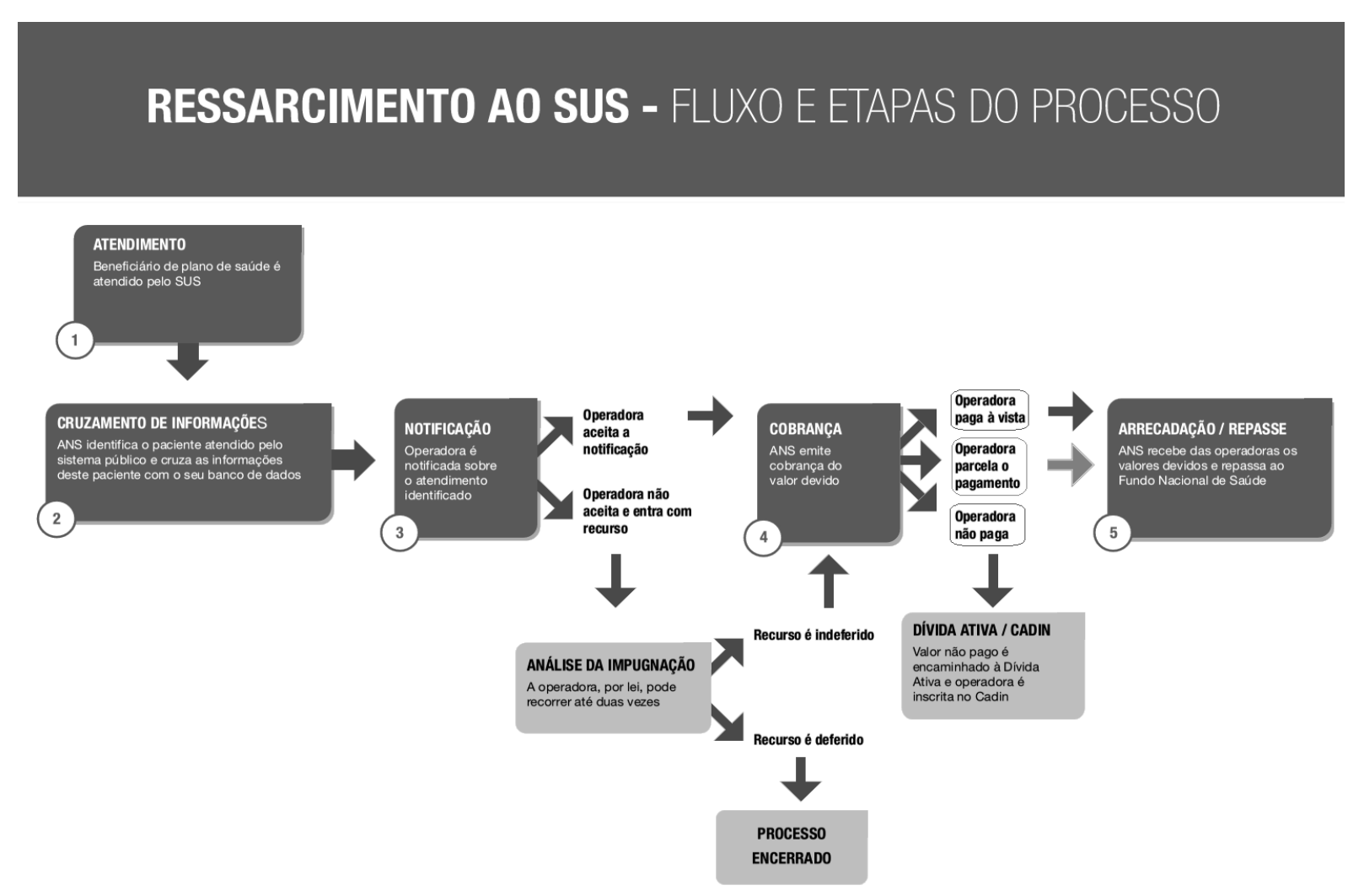

Fonte: ANS, 2016c.

Segundo dados da ANS, o item de número 5 diz respeito à Lei no 12.469/2011, que assegurou o repasse integral dos valores oriundos do Ressarcimento ao SUS para o Fundo 
Nacional de Saúde (FNS) que são aplicados em programas e ações estratégicas de responsabilidade do Ministério da Saúde. Todavia, não há clareza quanto à efetiva destinação dos valores. Por isso, infere-se que uma medida razoável seria o repasse desses valores ao fundo municipal ou estadual onde se realizaram os atendimentos/procedimentos no sistema público de saúde (BRASIL, 2016c).

Para a ANS, as inovações evidenciadas anteriormente representam a integração entre a saúde pública e a saúde suplementar, que, nesse novo desenho, busca, principalmente, agilidade dos serviços e redução de custos (BRASIL, 2014a).

A ANS divulgou, em 8 de maio de 2015, a ampliação do ressarcimento referente à cobrança de procedimentos de alta e média complexidade. Os gastos serão calculados conforme o seguinte detalhamento:

\begin{abstract}
exames e terapias ambulatoriais de alta e média complexidade passarão a ter seus valores ressarcidos ao Sistema Único de Saúde. É a primeira vez que as operadoras deverão fazer reembolso por esse tipo de atendimento, que é identificado por meio da Autorização de Procedimento Ambulatorial (APAC). A próxima cobrança do ressarcimento levará em consideração os registros de procedimentos de alta e média complexidade e internações realizados entre janeiro e março de 2014. Neste período, serão notificados $\mathbf{1 1 3 . 6 9 3}$ procedimentos com APAC e 76.258 internações de beneficiários de planos de saúde no SUS. De acordo com dados nacionais do primeiro trimestre de 2014, as internações correspondem a $40 \%$ do total de procedimentos que geram ressarcimento, e as APACs 60\%. Em termos financeiros, isso significa uma estimativa de cobrança de R \$ 173 milhões pelos exames e terapias de alta e média complexidade cobradas por APAC e R \$ 181 milhões em autorizações de internações. Vale lembrar que durante o processo administrativo a operadora poderá apresentar defesa e contestar a cobrança (BRASIL, 2015, grifos nossos).
\end{abstract}

Nesse novo formato de cobrança, a ANS pretende aumentar, em 149\%, o volume de procedimentos cobrados das operadoras de planos privados de saúde, pelos respectivos clientes que utilizarem o SUS (BRASIL, 2015).

\title{
2.4 Repercussões sobre a Cobertura Duplicada em Saúde
}

Nos argumentos de Santos (2009), a população brasileira dispõe de um sistema de saúde com cobertura duplicada. Esse fato torna-se um agravante na medida em que os 
portadores de planos e seguros privados de saúde são propensos a continuar utilizando o SUS, principalmente para os serviços mais caros.

Em função dos efeitos dessa cobertura duplicada, geram-se mais iniquidades no acesso, bem como se promove o setor privado de saúde. Isso porque resta à população com dificuldade de acesso ao SUS, buscar refúgio na rede particular de saúde. Segundo Noronha, Santos e Pereira (2011, p. 167) a população menos favorecida

que depende exclusivamente do SUS para o atendimento às suas necessidades de saúde esbarra na competição de serviços com quem tem planos e seguros públicos ou privados, tornando o sistema ainda mais perverso. Para os sem planos e seguros são acentuadas as já grandes dificuldades de acesso e de tempo em lista de espera para internações, exames complementares e consultas a especialistas.

Além disso, Santos (2009) revela que o financiamento parcial de planos privados de saúde para servidores públicos faz com que o Estado deixe de investir no SUS. Convém assinalar que o fato de ter aproximadamente $25 \%$ da população utilizando os serviços privados de saúde não significa que ocorra desafogamento/redução de milhares de indivíduos no sistema público. Para a mesma autora, o que chama a atenção é o fato de que esse tipo de sistema não atenua as iniquidades no acesso e "não diminui a pressão da demanda por serviços do sistema público e, tampouco, no financiamento desse sistema" (SANTOS, 2009, p. 97). Por isso, duplicam-se não somente a cobertura, mas também os gastos. A cobertura duplicada de saúde:

(i) contribui para a iniquidade na oferta, no acesso e no uso dos serviços; (ii) incentiva o desenvolvimento do setor privado nos serviços em que a população tem dificuldade de acesso no sistema público; (iii) não diminui a pressão da demanda por serviços do sistema público e, tampouco, no financiamento desse sistema e; (iv) não contribui para a preservação dos objetivos gerais do sistema de saúde de universalidade e equidade, de contribuição positiva aos resultados de saúde, ao desenvolvimento do próprio sistema de saúde - e dos objetivos sociais, como a melhoria das condições de vida da população (SANTOS, 2009, p. 159, grifos nossos).

Desse modo, como confirma a autora, o segmento suplementar não diminui as demandas no âmbito da saúde pública, mas sim, acarreta uma sobrecarrega. 


\subsection{Benefícios Fiscais destinados ao Setor Privado de Saúde}

O segmento privado de saúde pode contar com três relevantes fontes de recursos públicos que seguramente fortalecem cada vez mais este setor, sendo elas: "a dedução dos gastos com planos de saúde dos impostos devidos pelas empresas; a dedução dos gastos com planos de saúde do imposto de renda das pessoas físicas; e os gastos públicos com planos de saúde de servidores" (BAHIA, 2006, p. 163, grifo nosso).

A primeira e a segunda fonte de recursos tornam-se um forte instrumento para financiar indiretamente os planos privados de saúde. Já a última fonte financeira se concretiza mediante destinação de

recursos públicos para os planos privados de saúde provém dos gastos com o pagamento de planos de saúde privados para funcionários públicos. Esses gastos, que o atual Ministério do Planejamento pretende ampliar, apresentando-os como benefícios trabalhistas para garantir a cobertura de planos privados de saúde para todos os servidores federais e seus dependentes, contam com amplo respaldo de associações de funcionários e sindicatos de funcionários públicos, inclusive dos servidores das instituições de saúde (BAHIA, 2006, p. 164, grifos nossos).

Tais benefícios fiscais dizem respeito ao que o Estado perde no orçamento federal para favorecer o mercado de planos e seguros privados de saúde. Esse dilema se agrava quando servidores públicos lutam dentro e fora dos sindicatos por aumento da per capita para custear seus planos privados de saúde, mas deixam de lutar pelos mesmos investimentos para o SUS, uma vez que os referidos benefícios causam grave diminuição arrecadatória, assim como provocam o aumento da

disponibilidade econômica de determinado grupo de contribuintes. Na declaração de rendimentos da pessoa física podem ser deduzidos os pagamentos efetuados com mensalidades de planos de saúde, além de pagamento particular a médicos, dentistas, exames etc., desde que não tenham sido reembolsados (SCHEFFER; AZEVEDO; BAHIA, 2010, p. 230).

Em razão disso, a renúncia fiscal pode aumentar a oferta hospitalar privada, além de causar a "expansão do mercado de planos de saúde, por meio de apoio do Estado, em prejuízo ao financiamento do SUS e, consequentemente, à garantia do direito universal à 
saúde” (MENDES; WEILLER, 2015, p. 496). Os mesmos autores alertam que pessoas físicas e jurídicas podem ter redução dos respectivos pagamentos dos impostos de renda referentes aos custos com planos de saúde, assim como pela compra de serviços de saúde. Todavia, sem a definição de um teto para esses descontos, tal fato suscita um aumento exagerado desses benefícios tributários. Acrescenta-se que

\begin{abstract}
há incentivos ficais relacionados à demanda e à oferta de serviços privados de saúde. No que diz respeito à demanda, tanto a vinculação a planos de saúde quanto a utilização de serviços particulares são objeto de dedução integral do Imposto de Renda de Pessoas Físicas (IRPF) e do Imposto de Renda de Pessoa Jurídica (IRPJ). Mas a principal forma de dedução fiscal que as empresas empregadoras dispõem para abater os gastos com o pagamento parcial ou integral dos planos de saúde de seus empregados é a permissão legal para considerar as despesas com saúde como benefício trabalhista e, portanto, são computadas como custo operacional. Esse expediente permite tanto o abatimento dos gastos com os planos de saúde no imposto de renda bem como o repasse desses custos para os preços finais dos produtos e serviços, o que é pouco percebido pela sociedade (SCHEFFER; AZEVEDO; BAHIA, 2010, p. 229-230, grifos nossos).
\end{abstract}

Para exemplificar o custo operacional, esses autores argumentam que: ao se pagar uma conta telefônica, paga-se também o valor embutido do gasto referente aos planos de saúde dos trabalhadores da empresa de telefonia, afirmam, ainda, que apesar dos referidos gastos representarem entre $5 \%$ a $12 \%$ da folha de salarial, os mesmos não são considerados como um problema para os empregadores. Por isso, o que parece ser um ato digno de honrarias das instituições privadas na verdade é financiado pelos respectivos clientes.

\title{
2.6 Inserção do Capital Estrangeiro na Saúde
}

Anteriormente Fleury (2009) sugeriu que devemos conhecer o que está por trás da contratação de planos de saúde para servidores públicos. Sobre isso, Scheffer (2015a) responde que os apologistas do capital internacional, empresários inseridos no setor privado de saúde, são reconhecidos como os verdadeiros financiadores de campanhas eleitorais milionárias de políticos brasileiros que utilizam grandes redes midiáticas para convencer a 
população de que o SUS é uma utopia. Com isto, pretendem acumular mais capital com a comercialização desenfreada de planos privados de saúde.

As empresas privadas de saúde investem de forma crescente em cada eleição para eleger seus possíveis representantes, mas para Scheffer e Bahia (2015b), desde 2002, nenhuma instituição investiu mais no cenário político brasileiro que a Amil, que atua no ramo da Medicina de Grupo. Essa empresa quase internacional em sua totalidade, fato que será detalhado adiante, efetuou um donativo extraordinário no valor de $\mathrm{R} \$ 26.327 .511,22$ (milhões). Isto resulta em $48 \%$ do montante das doações realizadas por todas as empresas desse segmento nas eleições de 2014.

Atualmente, a Amil é quase toda formada por capital internacional, sendo que, era composta por capital nacional até o ano de 2011. Mas, um ano depois, a UnitedHealth Group, maior instituição de seguros privados de saúde dos Estados Unidos, comprou 90\% da empresa Amil, considerada uma das grandes operadoras de planos privados de saúde e provedora de serviços. Essa transação aproximou o risco do aumento da verticalização do mercado de saúde suplementar (SÁ et al., 2015).

Figura 2 - Modelos produtivos tradicional e verticalizado.

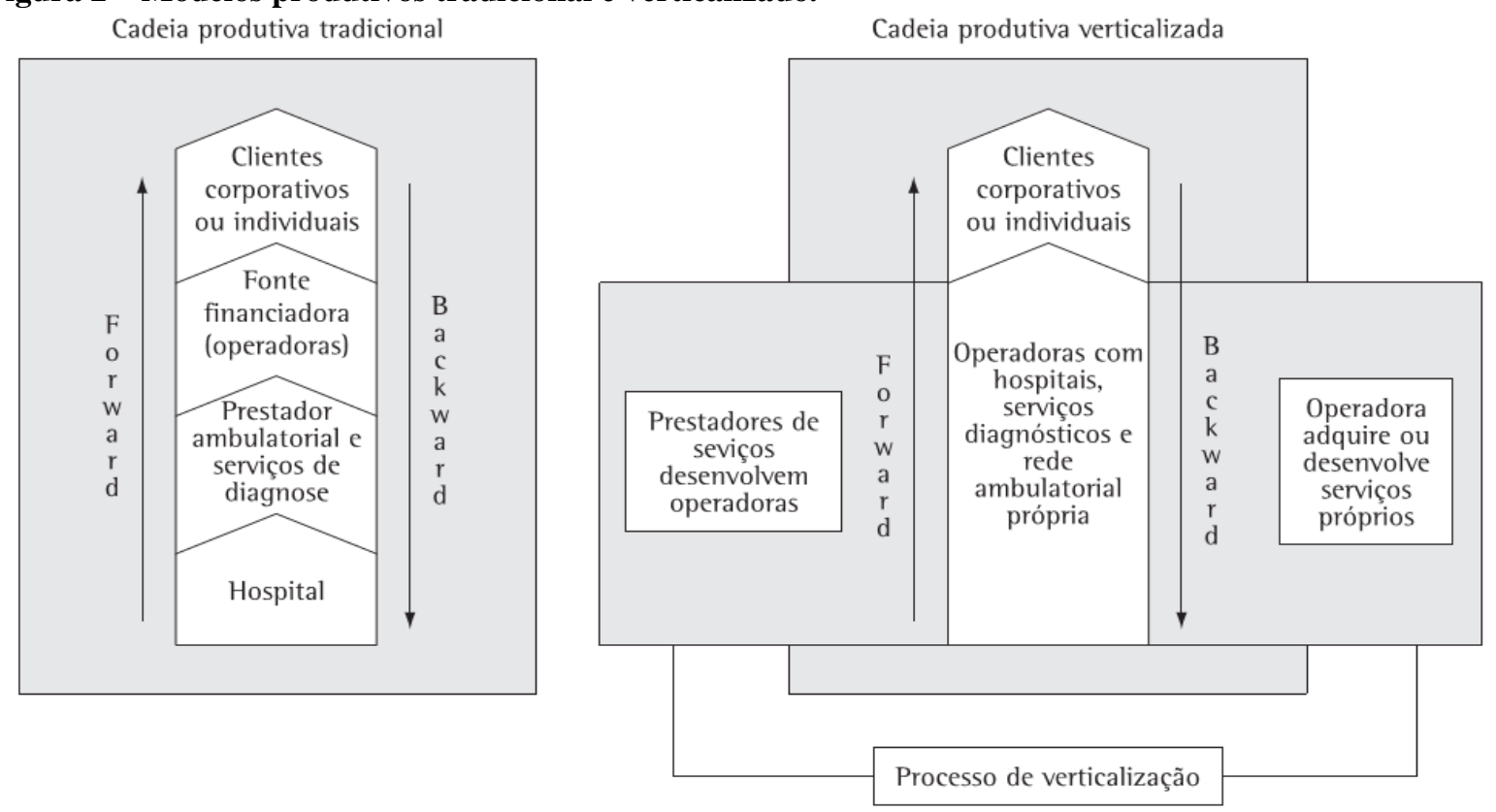

Fonte: Albuquerque; Fleury; A. L.; Fleury, M. T. L. (2011) 
$\mathrm{O}$ primeiro modelo produtivo apresentado na figura 2 revela um esquema de mercado constituído por diferentes instituições. O segundo modelo é basicamente formado por uma única empresa, em que certas operadoras de planos privados de saúde resolveram modificar suas estratégias de "atuação, verticalizando suas estruturas, ou seja, criando uma rede própria de atendimento (consultórios, pronto-atendimentos, laboratórios, raios-X, hospitais)" (SOUZA; SAVALAIO, 2010, p. 306). Segundo Albuquerque, Fleury, A. L. e Fleury, M. T. L. (2011, p. 8), o processo de verticalização em pauta "tem como objetivo maior controle dos custos de produção e vem ocorrendo principalmente entre as medicinas de grupo com grandes carteiras de beneficiários”.

A verticalização da saúde suplementar traz alguns riscos, pois ao buscar uma

verticalização que certamente reduz o custo de transação, as operadoras passaram a ter seus próprios hospitais, seus laboratórios de análises e a contratar médicos como assalariados, na maioria das vezes desrespeitando a legislação trabalhista e precarizando o vínculo (AZEVEDO JR.; SCHEFFER; BIANCARELLI, 2012, p. 37).

Por essas razões, as operadoras podem ampliar o controle sobre todos os serviços, assim como monopolizar esse segmento. Esses autores acrescentam ainda que o processo de verticalização estabelece um contexto gerido pela competitividade no qual a qualidade na prestação de serviços pode dar lugar à sustentabilidade do comércio.

Tudo isso, segundo Scheffer e Bahia (2015b), tem ligação com a defesa de interesses comerciais e particulares (lobby) praticado nas eleições para favorecer determinados grupos, em detrimento do caráter universal das políticas. Contra isso, resta ao povo não abrir mão do seu papel participativo. Em decorrência disso, 
grupos empresariais fortalecidos com o financiamento de campanhas e consequente proximidade com o núcleo dirigente do país, e que passam a requerer isenções, anistias fiscais e o não pagamento de multas e taxas administrativas, entrada de capital estrangeiro em seus negócios e na sua rede credenciada de hospitais e laboratórios, são os mesmos que constroem e disseminam uma narrativa sobre o fracasso e a falência do SUS (SCHEFER; BAHIA, 2015b, p. 40, grifos nossos).

Segundo Scheffer e Bahia (2015b, p. 5), o lobby das operadoras de planos privados de saúde é praticado mediante doações a futuros representantes políticos eleitos pelo voto. Tal ato não condiz com os interesses da população, pelo contrário, cria obstáculos para a correção das iniquidades.

É oportuno relacionar as instituições privadas que efetuaram grandes doações de recursos financeiros para campanhas eleitorais de 2014, das quais sobressaíram: Amil Assistência Médica Internacional S/A, Bradesco Saúde S/A, Qualicorp Corretora de Seguros S/A e Unimed, que doaram juntas a quantia de 51.873.011,22 milhões de reais (SCHEFFER; BAHIA, 2015b).

Esses autores alertam que, por coincidência ou projeção política em função do lobby, as três empresas que mais colaboraram com as campanhas eleitorais de 2014, aparecem, por exemplo, na lista de oferta do convênio entre a Aliança Administradora de Benefícios de Saúde e o Ministério da Educação (MEC) para ofertar planos privados de saúde aos servidores do Poder Executivo. 
Figura 3 - Empresas privadas de saúde que efetuaram doações eleitorais em 2014.

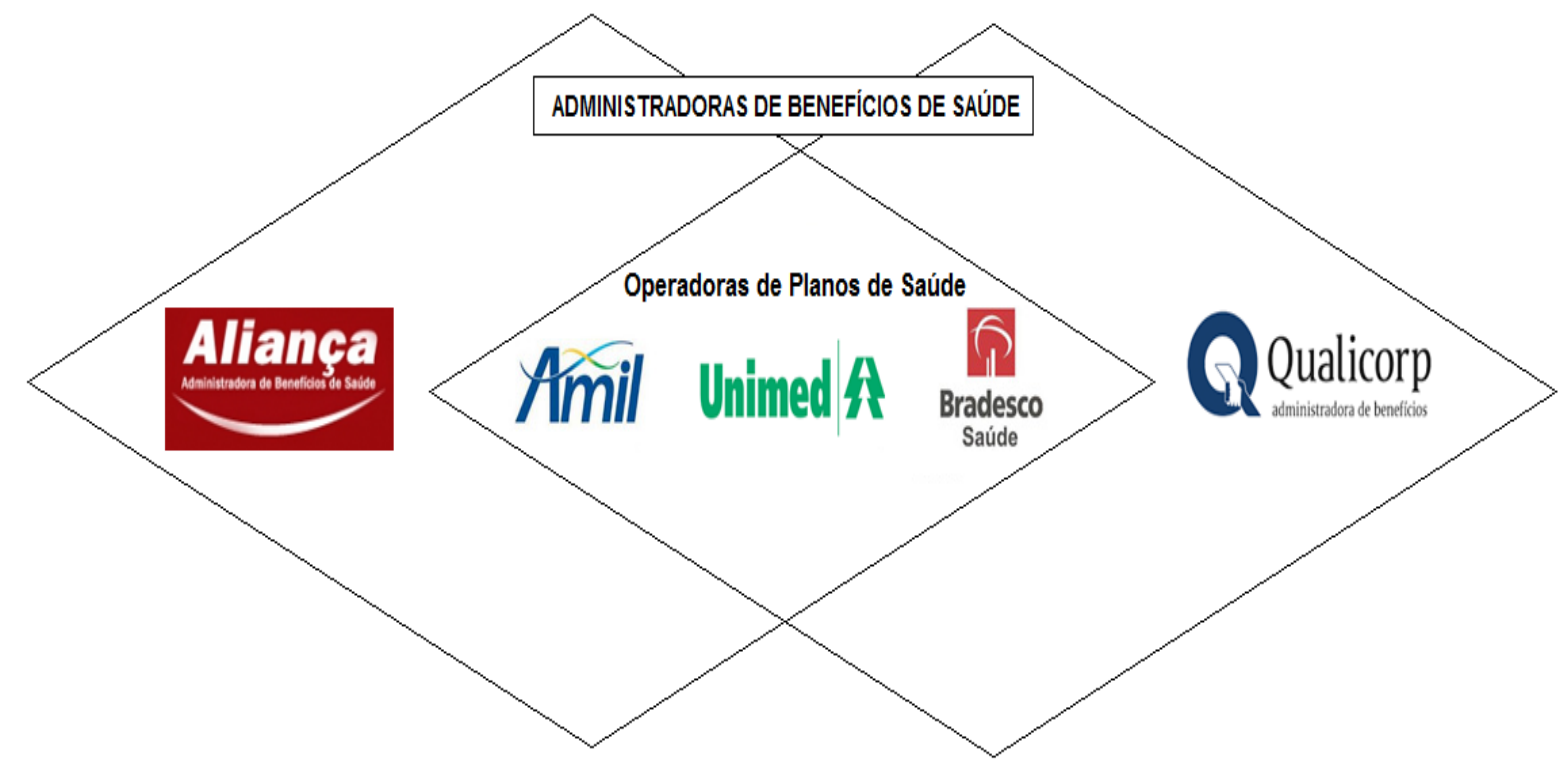

Fonte: Dados do estudo, 2016.

Curiosamente, o referido Grupo Aliança realizou doações no valor de R\$ 306.000,00 nas eleições de 2010 (SCHEFFER; BAHIA, 2013). Esta instituição comercializa planos de saúde das empresas: Amil, Assim Saúde, Blue Med Saúde, Bradesco Saúde DentalUni, Golden Cross, Hpvida, Medial Saúde, OdontoGroup, Odontoprev, Prodent, Unimed, Sul América Saúde, entre outras (ALIANÇA ADMINISTRADORA, 2016). A Qualicorp, administradora de benefícios de saúde, também vende planos de saúde das operadoras AMIL, Bradesco Saúde e UNIMED (QUALICORP, 2016). O texto a seguir confirma que as cinco empresas apresentadas estão entre as maiores doadoras de recursos financeiros para campanhas eleitorais; por conseguinte, essas firmas fazem parte do rol das que mais crescem no mercado de saúde privada em nosso país.

De acordo com Scheffer e Bahia (2015b), o segmento privado de saúde busca representantes em todos os espaços políticos. Para exemplificar, a Emenda no 379, de autoria do deputado Manoel Alves da Silva Junior, do PMDB-PB, intentava liberar a circulação de capital estrangeiro na área de saúde, sendo incluída na Medida Provisória 656 de 7 de outubro de 2014, que resultou na Lei $\mathrm{n}^{\circ}$ 13.097, sancionada pela Presidenta Dilma Rousseff (PT) em 
19 de janeiro de 2015. Estranhamente, na última eleição, o referido deputado recebeu doação da Bradesco Saúde Administradora de Benefícios de Saúde no valor de R\$ 105.667,66, enquanto a atual Presidenta da República foi beneficiada em sua reeleição com a quantia extraordinária de R\$ 11 milhões, sendo R \$ 7 milhões da Amil e R \$ 4 milhões da Qualicorp Administradora de Benefícios de Saúde.

Os planos de saúde fizeram doações eleitorais para 13 candidatos ao cargo de Governador. Três eleitos receberam recursos da rede privada de saúde, dos quais Geraldo Alckmin, do PSDB, foi o maior favorecido, com R\$ 1.633.400,69, oriundos da Amil; os outros dois foram apadrinhados pela Bradesco Saúde, Paulo Câmara, do PSB/PE, que angariou R \$ 500.000,00, e José Ivo Sartori, do PMDB/RS, com a quantia de R \$ 150.000,00 (SCHEFFER; BAHIA, 2015b).

Em 2014, três dos senadores eleitos também receberam ajuda financeira dos planos de saúde: Fernando Collor, do PB/AL, obteve R\$ 300.000,00 da Bradesco Saúde S/A; seguido de Ronaldo Caiado, do DEM/GO, com $\mathrm{R} \$ 100.000,00$ da Unimed do Brasil/Confederação Nacional das Cooperativas Médicas; por fim, o candidato Lasier Martins, do PDT/RS, ganhou $\mathrm{R} \$ 1.000,00$ da Unimed/RS Federação das Cooperativas Médicas do Estado do Rio Grande do Sul. Observou-se que o deputado Eduardo Cosentino da Cunha, do PMDB/RJ e Presidente da Câmara, foi presenteado em sua campanha pela Bradesco Saúde com R\$250.000,00. Outros 28 deputados federais foram eleitos com financiamento da rede privada de saúde, chegando o total de doações a esses 29 deputados ao patamar de R\$3.180.667,66 (SCHEFFER; BAHIA, 2015b).

Por fim, o setor privado de saúde, no intuito de ampliar o quantitativo de aliados em diferentes instâncias, apoiou de maneira pecuniária 24 deputados estaduais eleitos. A maior parte recebeu uma quantia na faixa de $\mathrm{R} \$ 5.000,00$ a $\mathrm{R} \$ 75.000,00$, ofertados principalmente pelas Unimeds. Além disso, duas instituições de planos de saúde locais 
contribuíram com maior valor - tais como a Samel, que financiou a campanha de Luis Nicolau (PSD) com o valor de R \$ 470.550,00; e a Oralclass, que doou R \$ 276.500,00 ao deputado Antônio de Albuquerque (PRTB) (SCHEFFER; BAHIA, 2015b). Por tudo isso, os portadores de planos privados de saúde, bem como a população em geral, devem estar atentos quanto às consequências negativas que essas doações podem trazer para o Sistema Único de Saúde.

Essas doações podem ter sido responsáveis pelo surgimento da Lei $\mathrm{n}^{\circ}$ 13.097/2015, que autorizou a participação direta ou indireta de empresas de capital estrangeiro nas ações de saúde. Indubitavelmente, essas modificações na legislação beneficiarão diretamente os empreendedores de hospitais particulares, empresas do ramo farmacêutico, e operadoras de planos privados de saúde, que, além de contar com o capital estrangeiro, poderão participar da formulação das políticas brasileiras de saúde.

De maneira corroborativa, Souza $(2015$, p. 5) assinala que essa lei permite

a participação direta e indireta de empresas ou capital estrangeiro na assistência à
saúde. A lei estimula o consumo individual de planos privados e rompe com os
preceitos constitucionais do acesso universal como dever do Estado e direito de
todos. A saúde suplementar movimenta mais de $\mathrm{R} \$ 100$ bilhões anuais e, por ser
doadora de campanhas eleitorais, passou a ter forte influência no Congresso e na
Agência Nacional de Saúde.

Além do que foi exposto, Scheffer (2015a) afirma que o Governo Federal exercerá o papel de avalista dos recursos financeiros estrangeiros destinados ao sistema de saúde, que utilizará o processo de desregulamentação, bem como práticas de incentivo ao uso de planos privados de saúde. Assim, a abertura ao capital estrangeiro e o fomento ao consumo de planos de saúde de baixo preço, com armadilhas contratuais e sérios problemas de cobertura, entre outros, proporcionarão concorrência desleal com o setor público, que financia integralmente os gastos em saúde no âmbito público e parcialmente no setor privado.

Sobre a discussão evidenciada, Sá et al. (2015) alertam que embora o investimento internacional possa gerar empregos e proporcionar a utilização de novas 
tecnologias no país, a falta de regulação adequada dos recursos estrangeiros poderá ampliar as desigualdades e elevar os gastos públicos diretos e indiretos destinados ao funcionamento do sistema privado de saúde, sendo que os benefícios tributários e a utilização da rede pública de saúde por clientes de planos de saúde afetam a equidade pretendida pelo SUS.

Além disso, o sistema privado de saúde provoca a migração expressiva dos profissionais da rede pública para a rede particular de saúde, assim como daqueles que atuam nas zonas rurais para as empresas situadas nas áreas urbanas, que geralmente oferecem maiores salários em comparação ao setor público. Em suma, os mesmos autores relatam que por um lado o investimento direto de capital estrangeiro poderá trazer poucos benefícios, por outro, ocasionará imensuráveis prejuízos à saúde pública (SÁ et al., 2015).

Contudo, de forma plausível, o Supremo Tribunal Federal (STF) resolveu dar fim à farra de donativos empresariais para candidatos políticos, ao declarar a inconstitucionalidade do financiamento de campanhas, a partir de 2016. Com essa medida, tem-se em mente atenuar o poder da influência empresarial sobre o poder estatal, bem como abrir espaço para disputas mais equilibradas nas eleições (MARTINS, M.; MARTINS, R., 2016). Trata-se de uma considerável decisão que certamente evitará grandes negociatas entre patrocinadores de campanhas e políticos que interferem diretamente no SUS. No entanto, para Sestelo, Souza e Bahia (2013), o setor público deve e pode fazer muito mais para controlar os interesses da dimensão econômica em prol das aspirações coletivas da população, que deve assumir, cada vez mais, uma postura participativa. Desse modo, o SUS não seria considerado um sistema para pobres, mas sim, um sistema para todos. Entretanto, o acesso à saúde depende principalmente do respeito ao princípio da equidade. Esses autores sinalizam que, para que isto ocorra, é muito importante valorizar produções acadêmicas capazes de evidenciar a dinâmica de comércio dos planos e seguros de saúde que envolve o atual modelo de assistência à saúde do Estado brasileiro. 
Na visão de Ocké-Reis (2010), o setor privado, cada vez mais capitalizado, atende minimamente seus beneficiários, os quais acabam sobrecarregando o SUS. Cabe ao povo pressionar o Estado visando aumentar o impacto do gasto público em saúde, bem como para regular o setor privado de saúde com foco no interesse público, em que a saúde deve ser percebida como um recurso à vida, opondo-se à visão exclusivamente mercadológica.

Para isso, a ANS deve melhorar o seu papel intervencionista, priorizando a unicidade do sistema público de saúde, a fim de que o Estado possa alcançar condições para universalizar o acesso à saúde. Gerschman et al. (2012, p. 471) assinalam que

\begin{abstract}
praticamente $80 \%$ dos hospitais têm contratos com a Unimed. Ou seja, a maioria dos hospitais presta serviços para uma mesma operadora. Isso significa que, na medida em que a prestação é concentrada em um número pequeno de operadoras de planos de saúde, ela se acomodará às exigências requeridas por elas. Assim, se não for exigido do hospital, no momento da contratação, melhor qualidade de infraestrutura, de serviços, de práticas profissionais, de atenção e de gestão, os prestadores hospitalares não serão obrigados a obedecer padrões mais apurados de atenção. Sem a obrigatoriedade de melhor atendimento à saúde dos beneficiários, passam a ser as principais operadoras (a Unimed, a Cassi e a Geap), que dominam o mercado de prestadores, as que definem a qualidade da assistência no país. De fato, a presença monopólica dessas três operadoras evidencia a enorme concentração de mercado.
\end{abstract}

Convém analisarmos de que maneira a população pode intervir para que o Estado consiga limitar o crescente desenvolvimento do setor privado de saúde, que, apesar de ser beneficiado com recursos da União, não atua com interesse público.

\title{
2.7 Interpretação do conceito de Direito à Saúde
}

A definição constitucional de saúde como direito de todos e obrigação do poder estatal não é suficiente para garantir efetivamente o acesso e utilização do SUS. Sobre isso, Ferraz e Vieira (2009) afirmam que os recursos da saúde são insuficientes em relação às grandes demandas da população, razão pela qual se torna imperativo realizar escolhas cada vez mais acertadas quanto ao uso do dinheiro público. Nesse cenário, o direito à saúde 
apresenta-se de forma limitada e não absoluta; por isso, convém avaliar se interpretamos corretamente o conceito desse direito estabelecido em nossa Carta Constitucional.

Sobre a questão levantada, os mesmos autores asseguram que

uma interpretação adequada do direito à saúde deve estar centrada nos princípios de equidade e universalidade, entendidos como igualdade de acesso a serviços e a ações de saúde necessariamente limitados por recursos escassos. Nesse contexto, no qual é simplesmente impossível dar atendimento ilimitado a todos, o princípio da equidade exige que os recursos escassos sejam distribuídos a fim de priorizar a redução ou a eliminação de diferenças entre indivíduos que advêm de fatores evitáveis e injustos (FERRAZ; VIEIRA, 2009, p. 246, grifos nossos).

O paradoxo que envolve o direito universal à saúde e a falta de cumprimento do mesmo pelas instituições acaba por incentivar a judicialização da política de saúde. Segundo argumentos de Fleury (2012, p. 159), “a judicialização das políticas diz respeito ao uso do recurso judicial como forma de exigibilidade do direito, denegado na prática das instituições responsáveis". A fim de complementar o que foi destacado, adiciona-se que

ao assumir a saúde como direito universal de cidadania, sem requisitos de contribuição prévia ou prova de incapacidade, o seu exercício passa a depender das necessidades dos indivíduos e das condições asseguradas pelo Estado para que o direito na lei se transforme em direito em exercício. Estas condições dependem das relações entre as forças sociais presentes na conjuntura. O fato de o SUS ter sido implantado em condições financeiras adversas, até hoje não superadas, certamente impede a distribuição igualitária de serviços de qualidade, de forma que a população sinta-se segura no usufruto deste direito (FLEURY, 2012, p. 159, grifos nossos).

Contrapondo-se ao que foi dito, Menicucci (2014, p. 90) afirma que há um crescente número de judicializações em função do antagonismo entre direitos individuais e coletivos, posto que "a justiça funciona pelo direito do indivíduo e prejudica o direito coletivo; mas ela só é possível a partir do que está na Constituição, que é direito de todos e dever do Estado". A alegação da saúde apresentada como um direito transformou-se em uma forte argumentação dos impetrantes, assim como dos juízes no ato de concessão de determinadas exceções.

Sobre isso, Fleury (2012) revela que a judicialização em prol da coletividade, poderá preservar a proteção do direito à saúde, principalmente, para defender o SUS das 
constantes ameaças advindas dos interesses do setor privado de saúde. Essa segurança jurídica poderá livrar a saúde pública dos riscos nacionais e internacionais pertinentes a privatização.

A saúde deve ser percebida como necessidade essencial assegurada em lei e deve ser ofertada à população por meio de acesso aos procedimentos, os quais englobam: “promoção, a prevenção, a manutenção e a recuperação, deverá ser objeto de políticas públicas universais e igualitárias assumidas como responsabilidade ética por toda a sociedade" (BARATA, 2008, p. 28).

Sabe-se que os principais aspectos inerentes ao acesso à saúde sinalizam que “acesso é um conceito complexo, muitas vezes empregado de forma imprecisa, e pouco claro na sua relação com a utilização de serviços de saúde. É um conceito que varia entre autores e que muda ao longo de tempo e de acordo com o contexto" (TRAVASSOS; MARTINS, 2004, p. 191). Convém acrescentar que o acesso é visto como "tema multifacetado e multidimensional envolvendo aspectos políticos, econômicos, sociais, organizativos, técnicos e simbólicos, no estabelecimento de caminhos para a universalização da sua atenção" (ASSIS; JESUS, 2012, p. 2868). De acordo com Travassos e Martins (2004), a utilização depende de fatores individuais e contextuais, sendo também uma das formas de alcançar o acesso. Geralmente, o termo "utilização" serve para expressar a inicialização dos serviços de saúde situados na primeira dimensão, que não se desvincula da oferta. Vale destacar que as condições de acesso, assim como de utilização dos serviços disponíveis na área de saúde,

\footnotetext{
podem ser pensadas como parte dos aspectos que compõem a vulnerabilidade programática, ou seja, que possibilitam ou não, aos diferentes grupos sociais, o acesso aos recursos necessários para fazer frente a seus problemas de saúde. Entretanto, a vulnerabilidade no acesso e uso de serviços de saúde relaciona-se também com as outras dimensões de vulnerabilidade, visto que as características demográficas e sociais são determinantes do uso de serviços, pelo lado da demanda. Uma política de saúde com as características do Sistema Único de Saúde procura, através da realização dos princípios da universalidade, integralidade e equidade, compensar, no plano do consumo, as desigualdades produzidas pela organização social (BARATA, 2008, p. 20).
} 
O acesso à saúde na atualidade pode ter relação direta com: aceitabilidade, informação, disponibilidade, capacidade de pagamento ou acesso econômico, acessibilidade geográfica/territorialização (SANCHEZ; CICONELLI, 2012; ASSIS; JESUS, 2012). No quadro abaixo serão apresentadas as características desses fatores.

Quadro 1 - Características dos fatores inerentes ao acesso à saúde.

\begin{tabular}{|c|c|}
\hline FATORES & ASPECTOS ENVOLVIDOS \\
\hline $\begin{array}{l}\text { Disponibilidade } \\
\text { Caracteriza-se pela existência dos serviços de } \\
\text { saúde em locais adequados e na ocasião das } \\
\text { necessidades da população, ou seja, diz respeito } \\
\text { ao local da oferta dos serviços em relação à } \\
\text { moradia dos usuários. }\end{array}$ & $\begin{array}{l}\text { Distância, meio de transporte, custos, horário de } \\
\text { funcionamento dos estabelecimentos de saúde, } \\
\text { realização de consultas não agendadas, } \\
\text { qualidade dos serviços prestados. }\end{array}$ \\
\hline $\begin{array}{l}\text { Aceitabilidade } \\
\text { Diz respeito à natureza dos serviços de saúde e } \\
\text { como são observados de forma individual e } \\
\text { coletiva. Pode ser compreendida como a } \\
\text { relação entre as } \\
\text { atitudes dos usuários, trabalhadores de saúde e } \\
\text { práticas dos serviços de saúde. }\end{array}$ & $\begin{array}{l}\text { Idade, estado civil, crenças culturais, sexo, } \\
\text { estado civil, tamanho da família, seguimento do } \\
\text { tratamento prescrito, religião, situação } \\
\text { socioeconômica, respeito e confiança entre } \\
\text { pacientes e profissionais de saúde. }\end{array}$ \\
\hline $\begin{array}{l}\text { Poder de pagamento } \\
\text { Relaciona-se diretamente com a capacidade de } \\
\text { pagamentos diretos ou indiretos dos serviços de } \\
\text { saúde públicos e privados. }\end{array}$ & $\begin{array}{l}\text { Exames, medicamentos, custeio de transporte, } \\
\text { alimentação, perda de renda, falta de crédito. }\end{array}$ \\
\hline $\begin{array}{l}\text { Informação } \\
\text { É indispensável para compreender cada } \\
\text { dimensão do acesso. Percepção individual } \\
\text { sobre saúde/doença, posto que a informação é } \\
\text { imprescindível para que um possível acesso } \\
\text { seja transformado em utilização dos serviços de } \\
\text { saúde. }\end{array}$ & $\begin{array}{l}\text { O nível educacional favorece o conhecimento } \\
\text { sobre saúde (letramento em saúde), gera } \\
\text { empoderamento dos indivíduos, possibilita } \\
\text { melhores escolhas sobre os cuidados com a } \\
\text { saúde, bem como fortalece o exercício da } \\
\text { participação popular/controle social. }\end{array}$ \\
\hline
\end{tabular}

Fonte: Adaptado de Sanchez e Ciconelli (2012).

Insere-se ainda o fator Acessibilidade Geográfica/Territorialização, que, segundo Assis e Jesus (2012), caracteriza-se pelo gasto com transporte, tempo de deslocamento, distância entre a residência do usuário e o local onde o serviço de saúde pode ser alcançado; ou seja, a acessibilidade aos serviços de saúde perpassa a dimensão geográfica. 
É necessário considerar que o fator financeiro interfere diretamente na adesão aos planos de saúde, entretanto, não basta possuir condição econômica capaz de manter o plano, posto que os planos de assistência à saúde selecionarão "preferencialmente os mais jovens (os sem doenças) e rejeitarão os mais velhos (os com doenças)" (CARVALHO, 2013, p. 23). Ademais, o autor afirma que os planos de saúde buscam realizar procedimentos simples e de custos irrisórios; por isso, os casos mais complexos, de alto custo, recaem sobre a rede pública, sob a justificativa da magnitude do direito universal à saúde.

Percebe-se com clareza que apenas o item Informação não se vincula a questão financeira. Assim sendo, a situação socioeconômica apresenta-se como determinante para o acesso à saúde. Acrescenta-se ainda que a saúde dos indivíduos congrega fatores sociais, biológicos, ambientais, econômicos, e não especificamente pelos cuidados médicos que podem acessar. “A atenção à saúde depende, portanto, de políticas multissetoriais abrangentes que vão muito além dos serviços médicos e do fornecimento de medicamentos" (FERRAZ; VIEIRA, 2009, p. 224). Contudo, a Organização Mundial da Saúde (OMS) adverte que

\footnotetext{
os governos devem também estar cientes que os serviços públicos gratuitos podem ser capturados pelos ricos, que os utilizam mais do que os pobres, mesmo que as suas necessidades sejam menores. Alguns grupos de pessoas são ignorados pelas falhas da maioria dos sistemas [...] (OMS, 2010, p. 19).
}

De forma a sintetizar o que foi elencado, note-se que o acesso é um fator que intermedeia a relação entre a procura e a entrada no serviço, pois se refere às características da oferta de serviço de saúde que facilitam ou obstruem a sua utilização (TRAVASSOS; CASTRO, 2012, p. 185-186).

Nos argumentos de Travassos e Martins (2004), o centro de funcionamento da rede de saúde está ligado à utilização dos seus serviços, que se caracterizam pela realização das consultas médicas, internações, exames preventivos, diagnósticos ou qualquer forma de contato direto e/ou indireto com o setor de saúde. Portanto, a utilização representa a interação do indivíduo que busca algum tipo de cuidado no sistema de saúde. 
A discussão acima permitiu visualizar que o acesso e a utilização dos serviços indispensáveis de saúde devem chegar a todos, independentemente da situação social. Contudo, a população mais vulnerável deve ser tratada de forma diferenciada para que assim as diferenças sejam abolidas ou diminuídas, tornando o acesso à saúde universal e igualitário (BARATA, 2009). Isto não significa tratar igualmente os usuários do SUS, posto que

em situações que ocorrem grandes desigualdades, como no acesso aos serviços de saúde, atender igualmente os desiguais poderia resultar na manutenção das desigualdades, impedindo atingir a igualdade. Com vistas sobretudo à distribuição de recursos, cresce a importância da noção de equidade [...]. (PAIM, 2009b, p. 45).

Dito de outra maneira, o autor assegura que a equidade pode ser alcançada por meio da condição de atender diferentemente os desiguais, ofertando atenção especial aos mais necessitados. Segundo Paim e Silva (2010), norteou-se pelos critérios de justiça para estabelecer a equidade horizontal que corresponde à igualdade de tratamento para os iguais, enquanto a equidade vertical é caracterizada pelo tratamento desigual dos indivíduos em suas diferenças. Para atenuar as diferenças ocasionadas por diversas razões entre os indivíduos que buscam os serviços disponíveis no SUS, atribui-se ao setor público o dever de

considerar a equidade como sendo a estratégia para se atingir a igualdade de oportunidades no tocante ao usufruto de boas condições de saúde e de acesso aos serviços de promoção, prevenção e recuperação, levando-se em conta as disparidades de ordem social, étnica, econômica e cultural. (DE BARROS; DE SOUSA, 2016, p. 16).

Na compreensão de Luiz e Jorge (2010, p. 115), a saúde deve ser guiada pela “ideia central de qualidade de vida e constitui um dos elementos da cidadania. Reafirma-se, assim, a equidade como um princípio que deve, necessariamente, permear toda e qualquer formulação e prática na área da saúde". Todavia, é necessário assinalar que "promover equidade em nosso contexto de país periférico é um desafio que deve ser seriamente considerado" (COELHO, 2010, p. 182). Dessa maneira, para cumprir o princípio da equidade no âmbito do SUS, faz-se necessário assumir o encargo de tratar desigualmente as pessoas 
com necessidades desiguais. Destarte, a equidade busca incluir os grupos mais necessitados de modo a diminuir o seu reverso, ou seja, minimizar as iniquidades. 


\section{ASPECTOS METODOLÓGICOS}

Com a finalidade de analisar os principais motivos da procura pelos serviços públicos de saúde do SUS por servidores ativos do IFG que possuem planos privados de saúde e as repercussões desta situação para a duplicidade do gasto público em saúde, foi realizado um estudo exploratório de caráter descritivo com abordagem quantitativa por meio do uso de amostragem não probabilística ou de conveniência.

\subsection{Tipo de estudo e Delineamento}

Segundo Sampieri, Collado e Lucio (2013), a pesquisa exploratória é utilizada principalmente quando envolve um tema pouco estudado. Já os estudos descritivos servem para especificar "as propriedades, as características e os traços importantes de qualquer fenômeno. Descreve tendências de um grupo ou população" (SAMPIERI; COLLADO; LUCIO, 2013, p. 102). De tal modo, o mesmo autor assevera que o resultado da combinação exploratório-descritivo permitirá aprofundar o conhecimento sobre a temática, além de possibilitar a caracterização do objeto em estudo.

A amostragem de conveniência é tipificada como não probabilística, por conseguinte, é cabível “quando o acesso a informações não é tão simples ou os recursos forem limitados, assim o pesquisador faz uso de dados que estão mais ao seu alcance" (GUIMARÃES, 2008, p. 15). Portanto, em função da impossibilidade para consultar os dados pessoais dos respondentes junto à ANS e operadoras de planos privados de saúde que possibilitariam a identificação dos procedimentos realizados pelos participantes da pesquisa na rede pública de saúde, optou-se pelo uso da amostragem de conveniência. 


\subsection{Cenário do Estudo}

A pesquisa foi realizada no âmbito do Instituto Federal de Educação, Ciência e Tecnologia de Goiás (IFG), que atualmente possui 14 campi, a saber: Águas Lindas, Anápolis, Aparecida de Goiânia, Cidade de Goiás, Formosa, Goiânia, Goiânia Oeste, Inhumas, Itumbiara, Jataí, Luziânia, Senador Canedo, Uruaçu e Valparaíso. Ainda se inclui na pesquisa o quadro de pessoal da Reitoria, situada na capital do estado (INSTITUTO FEDERAL DE GOIÁS, 2015).

\subsection{Sujeitos da Pesquisa}

O universo da pesquisa são todos os servidores federais que recebem auxíliosaúde da União para cobrir as despesas com planos privados de saúde. Como amostra, estabeleceu-se a participação mínima de 7\% dos 1.372 servidores ativos do IFG que recebem o referido auxílio e utilizaram o SUS nos últimos seis meses (BRASIL, 2016d). Deste modo, os 102 participantes correspondem a 7,4\% do total informado estando acima do limite estabelecido.

Em 25/01/2016, por meio do Sistema Eletrônico do Serviço de Informação ao Cidadão (e-SIC), protocolo nº 23480001478201672, questionou-se ao MPOG sobre:

1. Qual a quantidade de servidores federais no país distribuídos nos poderes Executivo, Legislativo e Judiciário. Com base na resposta, contabilizaram-se os servidores vinculados ao Executivo, 1.331.877 (milhão); Legislativo, 35.256 (mil); e Judiciário 158.386 (mil).

2. Qual foi o total de gasto público com o auxílio-saúde desses servidores no período de 2011 a 2014. O MPOG declarou que não foi possível responder a segunda questão, alegando que isto depende de apuração especial junto ao Serviço Federal de Processamento de 
Dados (SERPRO). Todavia, ressalte-se que esses 1.525.519 (milhão) servidores estão aptos a receber o auxílio-saúde (BRASIL, 2016e).

\subsection{Instrumental de Coleta de Dados}

Sendo parte do procedimento padrão utilizado para elaboração do referencial teórico, realizou-se primeiramente a revisão da literatura, que tem como premissa conhecer o que “já existe sobre o assunto, ou seja, sobre o estado da arte, oferecendo contextualização e consistência à investigação" (VERGARA, 1998, p. 34).

Outro instrumento de coleta de dados foi elaborado mediante adaptação de questionários validados extraídos dos instrumentais encontrados nas pesquisas produzidas por Pires et al. (2010, 2013). Esses materiais foram de suma importância para identificar os procedimentos mais utilizados pelos respondentes nos três níveis de atenção à saúde existentes no SUS, assim como da Pesquisa Nacional por Amostra de Domicílios (PNAD) de 2008, do Instituto Brasileiro de Geografia e Estatística (IBGE).

Isso porque, de acordo com o IBGE (2013), a PNAD faz parte de um sistema de pesquisas domiciliares responsáveis pela coleta de dados socioeconômicos e demográficos da população. Criado a partir de 1967, esse sistema tem como principal foco produzir informações basilares para subsidiar pesquisas sobre o desenvolvimento socioeconômico em nosso país, onde o Cadastro de Unidades Domiciliares é devidamente executado a cada ano. Além disso, são registradas as características profissionais, educacionais, condições de moradia, aspectos referentes à saúde pública e privada (planos de saúde médico e odontológico), segurança alimentar, entre outras informações relevantes para nosso trabalho, que considerou a dimensão responsável pela coleta de dados referentes às Características de Saúde dos Moradores. 
No pensamento de Travassos, Viacava e Laguardia (2008), a PNAD é uma importante fonte de conhecimento relacionada com os aspectos de saúde da população. De tal modo, o referido instrumento está diretamente relacionado com o foco desta proposta de pesquisa; portanto, sua utilização foi imprescindível.

Por meio do questionário devidamente adaptado foram recebidas todas as respostas referentes às variáveis: tipo de plano de saúde, utilização do SUS nos últimos seis meses, localização do local e serviço utilizado, problema de saúde da (atenção básica, média ou alta complexidade), ocorrência de internação, tempo de espera, lei de Ressarcimento ao SUS, avaliação do atendimento, possibilidade de reutilização do SUS e motivo, motivos da não utilização do plano de saúde, lotação dos servidores nos campi, cargos/carreiras, última titulação concluída, sexo, idade e remuneração. Com base nos resultados desse estudo, observou-se que essas variáveis contribuíram, entre outros, para traçar o perfil dos entrevistados, identificar os principais motivos de terem procurado o SUS, assim como mapear os procedimentos utilizados na rede pública de saúde por servidores ativos do IFG que recebem auxílio-saúde.

O questionário contido no Apêndice I foi aplicado exclusivamente no formato online, divulgado por meio da Comunicação Social/Reitoria do IFG e do Gabinete do campus Luziânia, que incluíram o questionário nas respectivas listas de e-mails institucionais. Contudo, em função do período de férias, muitos servidores não abriram o e-mail profissional, sendo, dessa forma, necessário avisar em reunião realizada com os docentes e técnicoadministrativos, reenviando e-mail, telefonando, assim como interagindo com alguns servidores multiplicadores que colaboraram com abordagens pessoais que reforçaram a importância de responderem ao questionário em pauta. Apesar do árduo trabalho de divulgação, alcançou-se a marca de 102 participantes, suficiente para dar continuidade ao estudo. 


\subsection{Análise de Dados}

Os dados coletados foram analisados com base na Estatística descritiva simples, cujo objetivo é sintetizar "as principais características de um conjunto de dados por meio de tabelas, gráficos e resumos numéricos" (GUIMARÃES, 2008, p. 12). Dessa maneira, foi possível analisar o perfil dos respondentes, identificar os principais motivos de terem recorrido ao SUS, bem como mapear os serviços e procedimentos utilizados por eles na rede pública de saúde.

Para avaliar as questões abertas recorreu-se à Análise de conteúdo, o que, segundo Vergara (1998), diz respeito ao estudo de documentos e textos. Essa técnica permite a utilização de processos sistemáticos, bem como deduções coerentes e inferências sobre o que foi respondido nas questões “Outros” do questionário aplicado.

Utilizou-se ainda o Teste do Qui-Quadrado desenvolvido por Karl Pearson para comparar variáveis nominais com duas ou mais categorias ao nível de significância de 5\%. Segundo Bruni (2012), trata-se de um teste não paramétrico que permite comparar possíveis divergências entre as frequências contidas na amostra com o que se pretende alcançar na população. Para tanto, fez-se uso da versão mais recente do programa Statistical Package for the Social Sciences (SPSS) ou Pacote Estatístico para as Ciências Sociais. 


\section{RESULTADOS E DISCUSSÃO}

Esta seção dispõe sobre os resultados e discussão dos achados responsáveis pela efetivação dos objetivos desta pesquisa. De acordo com os dados da tabela 1, cumpriu-se o primeiro objetivo específico deste estudo ao se traçar o perfil sociodemográfico de 30 (29\%) dos servidores ativos do IFG, contidos na amostra com 102 participantes. Segundo essa amostra, $72(71 \%)$ são clientes de planos privados de saúde, mas não utilizaram o SUS nos últimos seis meses.

Identificou-se nos estudos de Sanchez e Ciconelli (2012), Assis e Jesus (2012) e Paim et al. (2012) que, entre outros fatores, o perfil dos usuários do sistema público de saúde congrega informações relevantes para a discussão sobre saúde pública e privada no país, principalmente no que diz respeito à condição socioeconômica dos indivíduos. Por isso, seguem os perfis dos respondentes que utilizaram o SUS nos últimos seis meses.

Tabela 1 - Perfis dos servidores Técnico-administrativos e Professores do Ensino Básico, Técnico e Tecnológico (EBTT) do IFG que utilizaram o SUS nos últimos seis meses, por Nível de Atenção dos procedimentos realizados, Goiás, 2016.

\section{Nível de Atenção no SUS}

Variáveis

Sociodemográficas

\section{Atenção Básica}

$\mathrm{n} /(\%)$

Sexo

Feminino

Masculino

Subtotal

Faixa etária

24 a 28

29 a 33

34 a 38

39 a 43

54 a 58

Subtotal

Nível educacional

Doutorado

Mestrado

Especialização
$8(44)$

$10(56)$

$18(100)$

$1(5,6)$

$7(38,9)$

$5(27,8)$

$4(22,1)$

$1(5,6)$

18 (100)

$9(50)$

8 (44)
Média

Complexidade

$\mathrm{n} /(\%)$

7 (64)

4 (36)

11 (100)

$3(27,2)$

$4(36,4)$

$1(9,1)$

$2(18,2)$

$1(9,1)$

11 (100)

$1(9)$

$4(36,4)$

$4(36,4)$
Alta

Complexidade

$\mathrm{n} /(\%)$

$1(100)$

$16(53)$

14 (47)

$1(100)$

30 (100)

4 (13)

$11(37)$

$6(20)$

$6(20)$

$3(10)$

$1(100)$

1 (100)

30 (100)

$13(43,3)$ 


\begin{tabular}{lcccc}
\hline $\begin{array}{l}\text { Graduação } \\
\text { Subtotal }\end{array}$ & $1(6)$ & $2(18,2)$ & & $3(10)$ \\
Remuneração & $\mathbf{1 8 ( 1 0 0 )}$ & $\mathbf{1 1 ( 1 0 0 )}$ & $\mathbf{1}(\mathbf{1 0 0})$ & $\mathbf{3 0}(\mathbf{1 0 0})$ \\
1.500 a 2.499 & & & & $3(10)$ \\
2.500 a 3.499 & $2(11)$ & $1(9,1)$ & & $2(6,7)$ \\
3.500 a 4.499 & $1(5,6)$ & $1(9,1)$ & & $5(16,7)$ \\
4.500 a 5.499 & $3(16,7)$ & $2(18,2)$ & & $5(16,7)$ \\
5.500 a 6.499 & $1(5,6)$ & $4(36,4)$ & & $5(16,7)$ \\
6.500 ou mais & $5(27,8)$ & & & $10(33,2)$ \\
Subtotal & $6(33,3)$ & $3(27,2)$ & $1(100)$ & $\mathbf{3 0}(\mathbf{1 0 0})$ \\
\hline
\end{tabular}

Fonte: Dados do questionário do estudo, 2016.

Os perfis dos respondentes apontados na primeira tabela mostram que a utilização do sistema público de saúde por portadores de planos privados de saúde vai ao encontro do que Santos (2009) denomina de “dupla porta de entrada na saúde”. Para esse autor, o uso do SUS por clientes de planos de saúde proporciona elevação das iniquidades no âmbito da saúde pública, especificamente por gerar competição entre os indivíduos com e sem planos de saúde. Neste sentido, o Estado fortalece o setor privado de saúde, quando deveria priorizar o desenvolvimento do sistema público. Então qual seria a razão de aderirem a planos privados de saúde que não estão sendo utilizados?

Saliente-se que, essa questão tem vínculo com a questão tributária, pois utilizando ou não o plano privado de saúde contratado com recursos públicos, muitos dos entrevistados serão beneficiados nas Declarações do Imposto de Renda de Pessoas Físicas (SCHEFFER; AZEVEDO; BAHIA, 2010). É oportuno acrescentar que, segundo Garcia et al., (2015), o fato de não haver limite para a dedução fiscal dos gastos com a saúde torna-se um complicador para o financiamento do SUS.

Entre os respondentes, contam-se 16 do sexo feminino e 14 do sexo masculino que confirmaram a realização de procedimentos no sistema público de saúde nesse período. Embora o sexo feminino apareça em maior número, não foi possível confirmar esta supremacia estatisticamente, mediante o Teste do Qui-Quadrado. 
Calculou-se que 20 (67\%) entrevistados pertencem à carreira de técnicoadministrativo, que exige para os diferentes níveis: Ensino Fundamental, Ensino Médio, Ensino Médio + Curso Técnico ou Ensino Superior como requisitos mínimos para investidura no cargo. Entretanto, todos os entrevistados possuem formação além desses requisitos, todos são ao menos graduados. Por natureza do cargo, os 10 professores participantes são no mínimo graduados e representam 33\% do total de servidores nas duas carreiras.

Note-se que o nível educacional está bem acima do exigido nos editais de concursos do IFG para docentes e técnico-administrativos, posto que 27 (90\%) dos respondentes consultados possuem cursos de pós-graduação lato sensu e stricto sensu. Entre os professores investigados, um possui doutorado e todos os outros são mestres. De acordo com Sanchez e Ciconelli (2012, p. 266), “o nível de informação em geral, o qual está relacionado com o nível educacional dos indivíduos" influencia de maneira expressiva no acesso, assim como na utilização dos serviços/procedimentos de saúde. Dito de outra maneira, sob o aspecto educacional, os respondentes levam larga vantagem, se comparados aos indivíduos com baixa escolaridade.

Além do nível educacional foi possível constatar que apenas 3 (10\%) dos entrevistados percebem mensalmente até $\mathrm{R} \$ 2.499,00$. Os demais 27 (90\%) dos servidores do IFG se encontram nas faixas de remuneração entre $\mathrm{R} \$ 2.500,00$ a $\mathrm{R} \$ 6.500,00$ ou mais. Chama a atenção o fato de que 15 (50\%) deles ocupam a faixa de remuneração de $\mathrm{R} \$ 5.500$ a $\mathrm{R}$ \$ 6.500,00 ou mais. Tendo como parâmetro o atual salário mínimo de $\mathrm{R}$ \$ 880,00, calcula-se que os referidos percebem uma quantia mensal que varia entre dois e sete salários mínimos.

Sabe-se que o fator econômico interfere diretamente nas condições de acesso e utilização dos serviços de saúde. Partindo desse pressuposto, conforme Assis e Jesus (2012), a situação financeira dos participantes da pesquisa favorece esse grupo; assim como a falta de recursos prejudica muitos indivíduos, nas questões de transporte, compra de medicamentos e 
obtenção de serviços privados de saúde. Ao lado disso, os autores sinalizam que "pessoas inseridas nos grupos de renda mais baixa procuram menos os serviços de saúde ou apresentam menor probabilidade de usá-los” (ASSIS; JESUS, 2012, p. 2269).

Nos argumentos de Sanchez e Ciconelli (2012), a Capacidade de Pagamento ou affordability se traduz em possibilidade de financiamento dos serviços de saúde, ou seja, além do que foi elencado no parágrafo anterior, acrescentam-se as despesas diretas e indiretas com alimentação especial, exames e testes diagnósticos, manutenção em período de improdutividade profissional ou prejuízos nos rendimentos em função da saúde. Junto a isso, Sanchez e Ciconelli (2012) julgam ser importante expor sobre o subconceito Capacidade Financeira, ou ability-to-pay, que diz respeito ao crédito, patrimônio monetário ou de bens que possibilitam aos indivíduos cobrir suas despesas de saúde. Cabe assinalar que os participantes da pesquisa levam certa vantagem sobre os indivíduos de baixa renda e desempregados, pois os servidores públicos têm garantias contempladas nos conceitos (Capacidade de Pagamento e Financeira), tais como remuneração, crédito, bem como dos planos de saúde custeados de forma integral ou parcial pela União.

Confirmou-se que há diferença estatisticamente significativa ao nível de 5\%, entre o público considerado jovem pelas operadoras de planos privados de saúde, formado por 27 (80\%) dos pesquisados que se situam na faixa etária de 25 a 42 anos, e os 3 (10\%) indivíduos que possuem entre 55 e 56 anos. Embora a questão financeira evidenciada por Sanchez e Ciconelli (2012) possa exercer forte poder de influência sobre o acesso e utilização dos serviços de saúde públicos e privados, Carvalho (2013) afirma que as operadoras de planos de saúde excluem, por exemplo, os mais idosos, assim como os indivíduos doentes de qualquer idade; por isso, acrescenta que ter dinheiro, crédito e bens não significa necessariamente que será aceito pelas referidas operadoras. 
Nesse cenário, se os jovens que possuem planos privados de saúde preferem o SUS, assim como as operadoras não costumam aceitar idosos e pessoas com doenças préexistentes, torna-se difícil identificar o público efetivamente atendido pelas operadoras de planos de saúde.

Em vista disso, Ocké-Reis (2010) salienta que, por meio da equidade, o SUS deve buscar alternativas para acolher os indivíduos mais vulneráveis em detrimento aos privilegiados servidores públicos federais, que recebem auxílio-saúde para custear seus planos de saúde, assim como os de seus dependentes, posto que essa prática faz com que o Estado gaste duplamente para a mesma finalidade, tendo em vista que existe gasto público para manter o SUS. Na verdade, o gasto mencionado não é apenas duplo, mas sim triplo, ou seja, o primeiro gasto com saúde se dá no financiamento do SUS, o segundo refere-se ao pagamento total ou parcial de planos de saúde para servidores públicos federais, e o terceiro diz respeito aos benefícios fiscais.

Frente a isso, Ocké-Reis (2010) e Mendes e Weiller (2015) alertam que a concreta universalização da saúde pública se distancia, na medida em que o poder público investe menos recursos no SUS para incentivar amplamente a utilização dos serviços privados de saúde. Tais serviços arrastam boa parte dos recursos que deveriam ser aplicados unicamente no sistema público de saúde.

O segundo objetivo específico foi responsável pela identificação dos principais motivos da procura pelos serviços públicos de saúde do SUS por servidores ativos do IFG que possuem planos privados de saúde. Para responder sobre os principais motivos da utilização do SUS em detrimento ao uso do plano de saúde, os respondentes tiveram a liberdade de assinalar um ou mais itens, assim como puderam escrever livremente na alternativa "Outros". Por isso, apontando uma ou mais opções, os 30 entrevistados elegeram 44 itens que foram 
verificados mediante análise de conteúdo, assim como por meio de ferramentas informacionais que permitiram resultados mais precisos.

Em função da quantidade de servidores que possuem planos de saúde e utilizaram o SUS em um curto período de seis meses, tornou-se indispensável identificar os principais motivos da subutilização dos respectivos planos de saúde. Cabe lembrar que esses indivíduos recebem um auxílio-saúde do Estado para esta finalidade.

Este estudo revelou que 30 desses servidores procuraram o SUS por diversas causas, que serão elencadas na sequência.

Tabela 2 - Motivos de os servidores terem recorrido ao SUS nos últimos seis meses em detrimento ao uso dos planos privados de saúde, Goiás, 2016.

\section{Motivos da procura}

Falta de cobertura do plano de saúde

Por ter direito à saúde pública

Recursos hospitalares precários e/ou insuficientes oferecidos pelo plano de saúde

Carência do plano de saúde

Confiabilidade no SUS

Outros: Programa de governo; Consulta e vacinação imediata na

UPA; Consultar com médico da família

Total

Fonte: Dados do questionário do estudo, 2016.
$\mathrm{N} /(\%)$

$22(50)$

$7(16)$

$5(11)$

$3(7)$

$44(100)$

Comprovou-se estatisticamente que a falta de cobertura do plano de saúde foi apontada como sendo a principal causa de os servidores terem procurado o SUS nos últimos seis meses, pois $50 \%$ dos entrevistados indicaram esta falha seguida do direito à saúde, assim como dos recursos hospitalares precários e/ou insuficientes oferecidos pelo plano de saúde que totalizam $77 \%$ das afirmações. O Teste do Qui-Quadrado revelou que existe diferença estatisticamente significativa ao nível de 5,0 que permita destacar a falta de cobertura como principal motivador para que os servidores recorressem ao SUS.

Observou-se ainda que 7 (16\%) indivíduos reconheceram que procuram a rede pública de saúde em função do direito à saúde. Isso denota uma clara percepção quanto ao 
importante exercício da cidadania, que reconhece a saúde como um legítimo direito constitucional. Vale acrescentar que, "ao reconhecer o direito à saúde como direito social, vinculado à conquista de uma cidadania plena, rejeita a saúde como mercadoria" (PAIM, 2009a, p. 116). Além disso,

\begin{abstract}
a garantia dos direitos humanos básicos (sendo o principal o direito à vida) é premissa para qualquer sociedade que se suponha minimamente democrática. Nesse sentido, o direito à saúde se revela como condição fundamental para o exercício dos outros direitos sociais; sua garantia, conforme versa a Constituição, é referencial de desenvolvimento econômico e social do país. Ao adotarmos o direito à vida como um valor a ser defendido, assumimos o direito à saúde como ponto indiscutível das políticas sociais, como característica indispensável no exercício da cidadania. (PONTE; FALLEIROS, 2010, p. 274).
\end{abstract}

Em decorrência dos motivos elencados na tabela 2, os respondentes recorreram à rede pública de saúde em diversas localidades, mas Goiás se destacou pela execução da maior parte dos atendimentos. Isto é justificado pelo fato de os servidores do IFG possuírem assentamentos funcionais e/ou residirem nas cidades mencionadas na tabela 3 , coincidindo majoritariamente com os respectivos campi do Instituto Federal de Goiás.

Tabela 3 - Estados e Cidades onde os respondentes buscaram o SUS nos últimos seis meses, Goiás, 2016.

\title{
Local do atendimento
}

GO-Cidade de Goiás; Estrela do Norte e Santa Tereza de Goiás, Goiânia; Inhumas; Itumbiara; Jataí; Luziânia; Uruaçu; Urutaí; Valparaiso

DF-Brasília $\mathrm{N} /(\%)$

BA-Porto Seguro

PI-Teresina

RN-Natal

Total $30(100)$

Fonte: Dados do questionário do estudo, 2016.

Verificou-se nos dados da tabela 3 que os servidores ativos do IFG procuraram a rede pública de saúde mais intensamente no estado de Goiás, que atendeu 24 (80\%) dos casos confirmados como significativos pelo Teste do Qui-quadrado, geralmente onde moram ou trabalham.

Para identificar os serviços procurados pelos respondentes na rede pública, questionou-se qual o serviço de saúde do SUS que você e/ou seu dependente no plano de 
saúde buscou. As respostas apontaram que, as Unidades Básicas de Saúde atenderam 19 (63\%) desses respondentes; em segundo lugar situam-se as Unidades de Pronto-Atendimento (UPA), (pronto socorro ou emergência de hospital) que receberam 9 (30\%), por fim, os Ambulatórios ou Serviços Especializados responsáveis por apenas 2 (7\%) dos entrevistados atendidos. Por isso, infere-se que os planos de saúde não funcionam de maneira exitosa nessas regiões onde os servidores ativos do IFG buscaram o SUS, fato que põe em xeque a contratação dos respectivos planos de saúde considerados ineficientes.

Ressalta-se que o montante de mais de 3 milhões empregados anualmente pelo MPOG no financiamento de planos de saúde para servidores ativos do IFG é suficiente para sustentar por um ano o funcionamento de um dos novos campi do Instituto Federal de Goiás (BRASIL, 2016d). Assim, comprova-se que o auxílio-saúde não trouxe resultados positivos para os respondentes que procuraram o SUS, assim como o respectivo gasto público foi considerado ilógico.

Solicitou-se aos respondentes que informassem os procedimentos recebidos nos serviços do SUS. Com isto, foi possível relacionar os mais utilizados, que foram separados por nível de atenção à saúde, tais como Atenção Básica, de Média e Alta Complexidade, sendo que os 30 entrevistados apontaram o que buscaram e usaram no SUS.

Tabela 4 - Procedimentos mais utilizados no SUS pelos respondentes nos últimos seis meses, Goiás, 2016.

\section{Atenção Básica}

\section{Nível de Atenção no SUS}

$\mathrm{N} /(\%)$

Consultas de enfermagem (nível superior)

Ações programáticas - Saúde da Criança/Crescimento e Desenvolvimento

(CD), vacinação, palestras, etc.

Vacinação

Ações programáticas - Saúde da Mulher (pré-natal, preventivo,

planejamento familiar, etc.)

Subtotal

$18(100)$

Média Complexidade

Consultas médicas com especialistas

Exames de patologia clínica, Diagnóstico por imagem (Ultrassonografias,

Ecocardiografia, Endoscopia, Eletrocardiograma (ECG),

Eletroencefalograma (EEG), RX) 
Procedimentos hospitalares especializados

Procedimentos traumato-ortopédicos

Subtotal

Alta Complexidade

Cirurgia de reconstrução de mama

Total

Fonte: Dados do questionário do estudo, 2016.
$2(18,2)$

$1(9,1)$

11 (100)

30 (100)

O terceiro e último objetivo específico deste estudo cumpriu-se com a realização do mapeamento dos procedimentos do SUS utilizados nos últimos seis meses por servidores do IFG que possuem planos privados de saúde. Os dados contidos na tabela 4 confirmam que os respondentes não recorreram ao plano de saúde nem mesmo para resolver questões simples de saúde que são de cobertura obrigatória, sobrecarregando o sistema público na busca de serviços que deveriam ser disponibilizados pelas operadoras de planos de saúde.

Na Atenção Básica destacaram-se as consultas de enfermagem de nível superior, e ações programáticas referentes à saúde da criança são responsáveis pelos atendimentos de 14 entrevistados. Contudo, somando-se sete consultas da Atenção Básica com as seis realizadas com especialistas da Média Complexidade chega-se ao total de 13 nos dois níveis de atenção. Isto confirma que os planos de saúde dos respondentes não estão cumprindo suas obrigações legais, pois, de acordo com a ANS, essas 13 consultas realizadas no SUS pelos servidores ativos do IFG fazem parte dos requisitos mínimos para a comercialização de planos privados de saúde (BRASIL, 2016c).

O grande problema de migração da clientela dos planos de saúde para o SUS vivenciado pela administração pública não existiria se os serviços privados de saúde fossem exclusivamente complementares aos da rede pública, ou seja, a rede privada de saúde se limitaria a ofertar serviços não existentes no sistema público (CARVALHO, 2013). Para o autor, o SUS não deve ser apontado como política fracassada em comparação com a rede privada de saúde, tal como os planos privados de saúde aparecem enganosamente na mídia, como uma panaceia. Tendo em vista que esse setor cresce principalmente por meio da 
renúncia fiscal, o Estado potencializa as empresas de planos de saúde, quando deveria fortalecer a saúde pública em prol dos cidadãos.

De modo corroborativo, Gerschman (2008) relata que desde os primórdios, o setor privado de saúde surgiu no Brasil em razão de um nicho de mercado, por isso não causa espanto constatar que nos dias atuais este setor ainda não funcione de modo complementar à rede pública de saúde. A autora alerta que isto afeta gravemente o SUS e o cidadão que paga ao mercado por serviços de saúde ofertados gratuitamente pelo Estado. Além disso, ela acrescenta que enquanto nos países da União Européia o setor privado de saúde foi criado para adequar-se à saúde pública já estabelecida, em nosso país, ocorreu justamente o contrário. Assim, a criação tardia do SUS associada à imperfeita regulação do setor privado de saúde dificulta a respectiva relação público-privado; mais que isto, compromete o exercício da cidadania.

Entre o Brasil e Portugal há semelhanças e divergências no campo da saúde. Para Santos, Giovanella, et al. (2015), o sistema de saúde brasileiro se assemelha ao Serviço Nacional de Saúde (SNS) existente em Portugal, pois ambos dispõem de um sistema público de cobertura universal. Contudo, em Portugal e nos demais países da União Europeia são cobradas taxas moderadoras com diversos valores ${ }^{3}$, dos usuários que possuem condição de pagamento no ato da prestação dos serviços ou via boleto em caso de falta momentânea de recursos. Por meio dessas taxas, Portugal busca limitar a utilização abusiva de consultas, assim como dos procedimentos realizados na saúde pública. Todavia, nos países da União Europeia há uma previsão legal de isenção de taxas moderadoras, assim como de redução de encargos direcionados aos grupos considerados mais vulneráveis. Foi observado que não há ressarcimento ao Serviço Nacional de Saúde português quando utilizado por pessoas que possuem planos privados de saúde.

${ }^{3}$ Em Portugal, os serviços de urgência cobram taxas moderadoras entre 14,00 e 18,00 euros (PORTUGAL, 2016). 
Saliente-se que o SUS é público, universal, não cobra qualquer taxa de seus usuários, ricos ou pobres, portadores ou não de planos de saúde que utilizam esse sistema. Frente ao que foi relatado, não há lugar para dúvida: recorrendo ao SUS ou não, a falta de cobertura obrigatória estipulada pela ANS vulnerabiliza o acesso aos planos privados de saúde, geralmente contratados com recursos públicos. Logo, o gasto público em saúde falha em sua principal função, a qual, nos argumentos de Barata (2008), Pires et al. (2010), OMS (2010) e Carvalho (2013), o Estado não pode perder de vista: o dever de promover, proteger e recuperar a saúde no âmbito do SUS.

A próxima tabela contém informações sobre o tempo de espera dos entrevistados do nos três níveis de atenção à saúde do SUS.

Tabela 5 - Tempo de espera desde a chegada até a conclusão dos atendimentos recebidos pelos respondentes que utilizaram SUS nos últimos seis meses, Goiás, 2016.

\begin{tabular}{lcccc}
\hline $\begin{array}{l}\text { Tempo de } \\
\text { Espera }\end{array}$ & $\begin{array}{c}\text { Nível de Atenção no SUS } \\
\text { Atenão Básica } \\
\mathbf{n} /(\boldsymbol{\%})\end{array}$ & $\begin{array}{c}\text { Média } \\
\text { Complexidade } \\
\mathbf{n} /(\%)\end{array}$ & $\begin{array}{c}\text { Alta } \\
\text { Complexidade } \\
\mathbf{n} /(\boldsymbol{\%})\end{array}$ & Total \\
Menos de 30 min & $9(50)$ & $1(9,08)$ & & $\mathbf{N} /(\%)$ \\
De 31 min a 1h & $5(27,76)$ & $3(27,3)$ & & $8(33,3)$ \\
De 1h a 2h & $1(5,56)$ & $3(27,3)$ & & $4(13,33)$ \\
De 2h a 4h & $1(5,56)$ & $3(27,3)$ & & $4(13,33)$ \\
De 4h a 6h & & $1(9,08)$ & & $1(3,33)$ \\
De 6h a 8h & $1(5,56)$ & & & $1(3,33)$ \\
Mais de 8h & $1(5,56)$ & & $1(100)$ & $2(6,67)$ \\
Total & $\mathbf{1 8 ( 1 0 0 )}$ & $\mathbf{1 1}(\mathbf{1 0 0})$ & $\mathbf{1 ( 1 0 0 )}$ & $\mathbf{3 0}(\mathbf{1 0 0})$ \\
\hline
\end{tabular}

Fonte: Dados do questionário do estudo, 2016

Constatou-se nos resultados obtidos por meio do Teste do Qui-Quadrado que 22 (73\%) dos respondentes obtiveram rapidez no atendimento, posto que, do momento em que chegaram às unidades da rede pública de saúde até a conclusão dos atendimentos, o tempo de espera foi estimado entre $\mathbf{3 0}$ minutos e duas horas, sendo considerado como ágil (PIRES et $a l, 2010)$. É oportuno assinalar que 18 (60\%) dos entrevistados foram atendidos em um tempo hábil de até uma hora. 
Contabilizaram-se apenas três internações dos respondentes, denominados R1, R2 e R3, que informaram onde receberam os cuidados com a saúde, assim como suas pretensões de retornarem ao sistema público de saúde:

R1: foi atendida em hospital no nível de Atenção à Saúde de Alta Complexidade, especificamente para realizar cirurgia plástica de reconstrução de mama. Afirmou que se trata de uma demanda específica do SUS, que foi "bem atendida" por "ótimos profissionais" e que possivelmente retornará ao SUS pelo atendimento e por ter “direito à saúde pública".

R2: esta respondente recorreu ao Centro Integral de Atenção à Saúde (CAIS) e acrescentou que retornará à rede pública de saúde sob alegação de que “o atendimento no CAIS é melhor que o realizado pelo plano de saúde”.

R3: informou ter sido atendido em Clínica Médica e sinalizou que voltará ao SUS “em caso de necessidade”, ligada ou não à “falta de cobertura do plano de saúde".

Cabe acrescentar que na compreensão de Sá et al. (2015), o setor privado de saúde fomenta o consumo de planos de saúde com preços abaixo da média comercial, todavia, sujeitos a incontáveis falhas contratuais e, principalmente, com sérios problemas interligados a falta de cobertura. Por isso, o princípio da transparência pública deve ser cumprido de tal forma que povo brasileiro possa conhecer e discutir mais intensamente sobre os aspectos da assistência à saúde suplementar destinada aos servidores pertencentes à esfera federal. Dessa maneira, os referidos precisam conhecer detalhadamente sobre os aspectos do Ressarcimento ao SUS. Sabe-se que o Ressarcimento ao SUS foi instituído em 1998, contudo, mesmo depois de 18 anos de sua existência, não se identificam as causas do desconhecimento entre os respondentes sobre esse instrumento.

Verificou-se que apenas 7 (23\%) dos servidores que utilizaram a rede pública nos últimos seis meses estão cientes quanto às regras do ressarcimento em pauta. Em contrapartida, 23 (77\%) declararam não conhecer o mecanismo mencionado. Vale questionar 
se a referida desinformação se vincula à falta de interesse dos servidores ou às falhas da ANS no processo de divulgação que prejudica o empoderamento da população.

É perceptível que a maioria dos respondentes não conhece as leis e regras que dizem respeito ao Ressarcimento ao SUS. Essa constatação evidencia grave deficiência no processo de divulgação desse mecanismo por parte da ANS. Tendo em vista que o MPOG autoriza a formalização de convênios entre órgãos públicos e operadoras de planos privados de saúde a fim de ofertar planos de saúde e odontológicos aos servidores federais - em atividade ou não, aos pensionistas, assim como aos respectivos dependentes -, faz-se necessária uma participação mais efetiva da população nesse processo.

Para tanto, não basta publicar as leis e regulamentos. Para além disso, a ANS precisa divulgar essas questões incessantemente para fortalecer o exercício do controle social explicitado pelas autoras Sanchez e Ciconelli (2012), e reforçado por Scheffer e Bahia (2015b), sob a afirmação de que não convém ao povo abrir mão das participações populares. Segundo Brasil (2014b), o crescimento da dívida ativa das referidas operadoras cresce assustadoramente, fato este que pode ser justificado pela falta de rigor da ANS, assim como pela publicidade ineficiente.

O nível de satisfação dos 30 servidores ativos do IFG sobre os atendimentos recebidos no SUS nos últimos seis meses foi mensurado por meio de escala tipo Likert com cinco alternativas que classificaram o sistema público de saúde como: péssimo =1; ruim = 7; indiferente $=2 ;$ regular $=11$ e ótimo $=9$. Essa escala foi desenvolvida por Rensis Likert e tem como característica constatar o grau concordante e discordante sobre determinado assunto ou fato. Com isso, foi possível avaliar o nível de aceitação/reprovação do SUS (SILVA JUNIOR; COSTA, 2014).

Constatou-se significância estatística ao nível de 5\% para afirmar que os conceitos "péssimo" e "ruim" foram assinalados por 8 (27\%) dos respondentes, enquanto 20 (67\%) dos 
participantes afirmaram que a qualidade da atenção recebida pode ser classificada como regular e ótima. Isto nos faz acreditar que alguns entrevistados consideram a rede pública de saúde superior aos planos de saúde contratados com recursos públicos. Vale ressaltar que esses indivíduos recebem remuneração mensal entre $\mathrm{R} \$ 4.500,00$ a 6.500,00 ou mais, sendo eles: doutores, mestres, especialistas e graduados.

Reforçando o que foi exposto por Sanchez e Ciconelli (2012), assim como pelos autores Assis e Jesus (2012), quanto à interferência do nível educacional e da situação econômica no acesso e na utilização dos serviços de saúde, salienta-se que além do conhecimento, da faixa de remuneração bem acima da realidade dos cidadãos assalariados que dependem unicamente do SUS, os respondentes ainda recebem um valor per capita para financiar planos privados de saúde com direito a inclusão de dependentes. Por isso, duplicam as chances de acesso e utilização da saúde. 


\section{CONCLUSÕES}

Investigaram-se as causas que levaram os servidores ativos do IFG e/ou seus dependentes a utilizarem a rede pública de saúde, em detrimento ao uso do plano privado de saúde. Na medida em que os servidores passam a receber o auxílio-saúde, naturalmente deixam de defender os interesses do SUS, pois o aumento do valor per capita do referido auxílio pago pela União passa a faz parte do ponto de pauta dos sindicatos, ou seja, são usuários do setor público de saúde, mas defendem com veemência os interesses pessoais que fortalecem cada vez mais o setor privado de saúde.

Por um lado, a literatura analisada possibilitou constatar que o setor privado de saúde elege criteriosamente os seus clientes, dando preferência aos mais jovens e sadios que possuem condições de pagamento. Isso significa que os perfis dos entrevistados correspondem aos questionáveis pré-requisitos das operadoras de planos de saúde. Além disso, esses clientes pagam, mas não usam os planos de saúde, fortalecendo, assim, o mercado e enfraquecendo o SUS.

Constatou-se que os servidores ativos do IFG que utilizaram a rede pública de saúde nos últimos seis meses, são em sua maioria jovens, com boas condições de renda e elevado grau de escolaridade, se comparados aos cidadãos que dependem exclusivamente do SUS. Ao lado disso, comprovou-se que os planos de saúde não ofertaram aos entrevistados nem mesmo os atendimentos mínimos e obrigatórios estabelecidos em lei. Entre os motivos de terem procurado o SUS mais intensamente nos níveis de atenção básica e de média complexidade em detrimento à utilização do plano de saúde, os participantes elegeram em primeiro lugar a falta de cobertura dos planos de saúde; em segundo, afirmaram que isto se deve ao exercício da cidadania que congrega o direito universal à saúde assegurado na Carta Constitucional. Vale enfatizar que foi observado um elevado índice de desconhecimento dos 
participantes sobre os aspectos legais do Ressarcimento ao SUS pelas operadoras de planos privados de saúde, que, por sua vez, compromete o poder de pressão da sociedade, especialmente dos estratos médios formadores de opinião sobre o Estado.

Por outro, verificou-se que o SUS atua com foco na universalidade do acesso e utilização dos serviços de saúde e não escolhe seus usuários por meio do artifício de seleção perversa praticado pelo mercado de saúde. A rede pública de saúde abarca toda a população (brasileiros, estrangeiros, preteridos pelas operadoras), inclusive os clientes de planos de saúde. Portanto, para vencer este cenário desfavorável ao SUS, a sociedade deve estar no centro das discussões, para que, mediante pressão popular, possa levar o Estado a ampliar o gasto na saúde pública, bem como desenvolver um aprimoramento da regulação do setor privado de saúde. Ao longo deste estudo, verificou-se que o financiamento do SUS e as despesas com planos de saúde para servidores públicos federais resultam em duplicidade do gasto público em saúde. Contudo, identificou-se que a renúncia fiscal é mais um tipo, ou seja, confirma-se a ocorrência de triplicidade de gasto público em saúde, que deve ser reduzida em favor do Sistema Único de Saúde.

Por tudo isso, conclui-se que o SUS pode se transformar em nossa melhor opção para receber os mais diversos cuidados com a saúde. Embora esse sistema apresente algumas deficiências, ainda assim, é disponibilizado a todos. Nesse contexto, o Estado atuará expressivamente na contramão da universalização da saúde pública se persistir sustentando o setor privado de saúde por meio da renúncia fiscal. Esta situação se agrava devido à ineficiência da ANS na regulação do setor privado de saúde, ratificada pelo alto índice de inadimplência das operadoras referente ao Ressarcimento ao SUS, assim como pelo financiamento de planos de saúde para servidores públicos federais. Neste caso, o auxíliosaúde não reduz as demandas direcionadas à rede pública de saúde, pois além de aumentá-las, aprofunda as iniquidades no acesso ao Sistema Único de Saúde e na utilização dele. 


\subsection{Recomendações para novos estudos}

Conforme argumentos de Sampieri, Collado e Lucio (2013), uma das funções da pesquisa exploratória consiste em servir de base para o desenvolvimento de novos estudos. Em razão dessa afirmativa, sugerem-se algumas possibilidades para a realização de futuros estudos, a saber:

- Analisar, em âmbito nacional, os efeitos no SUS gerados pelo gasto público com o financiamento de planos de saúde para todos os servidores públicos federais (ativos, inativos, dependentes e pensionistas).

- Analisar o impacto da utilização do SUS pelos servidores federais quanto a equidade, acesso e uso nas pessoas que dependem exclusivamente do sistema público de saúde.

- Realizar estudo comparado para verificar o impacto financeiro do Ressarcimento ao SUS versus Taxas Moderadoras praticadas pelo sistema público de saúde em Portugal.

Com isto, espera-se que as novas pesquisas possam ampliar o conhecimento da população para fortalecer o debate sobre a saúde nos âmbitos público e privado. 


\section{REFERÊNCIAS}

ALBUQUERQUE, G. M. de; FLEURY, M. T. L.; FLEURY, A. L. Integração vertical nas operadoras de Assistência Médica Privada: um estudo exploratório na região de São Paulo. Revista Produção, São Paulo, v. 21, n. 1, p. 39-52, 2011.

ASSIS, M. M. A.; JESUS, W. L. A. de. Acesso aos serviços de saúde: abordagens, conceitos, políticas e modelo de análise. Ciência \& Saúde Coletiva, v. 17, n. 11, p. 2865-2875, 2012.

AZEVEDO JUNIOR, R.; SCHEFFER, M.; BIANCARELLI, A. Os médicos e os planos de saúde: guia de direitos contra os abusos praticados pelas operadoras. São Paulo: Conselho Regional de Medicina do Estado de São Paulo, 2012.

BAHIA, L. 25 anos de SUS: problema na saúde é político [entrevista na internet]. Recife: Portal DSS Nordeste, 2013 ago 21. Entrevista concedida a Maira Baracho. Disponível em: $<$ http://dssbr.org/site/entrevistas/25-anos-de-sus-problema-na-saude-e-politico/> Acesso em: 16 maio 2015.

BAHIA, L. Avanços e percalços do SUS: a regulação das relações entre o público e o privado. Trabalho, Educação e Saúde, Rio de Janeiro, v. 4, n. 1, p. 159-170, mar. 2006.

BARAtA, R. B. Acesso e uso de serviços de saúde. São Paulo em Perspectiva, v. 22, n. 2, p. 19-29, 2008.

BARATA, R. B. Como e por que as desigualdades sociais fazem mal à saúde. Rio de Janeiro: Fiocruz, 2009.

BRASIL. ANS amplia o ressarcimento com a cobrança de procedimentos de alta e média complexidade. Notícias ANS, Rio de Janeiro, 8 maio 2015. Disponível em: <http://www.ans.gov.br/aans/noticias-ans/integracao-com-o-sus/2841-ans-amplia-oressarcimento-com-a-cobranca-de-procedimentos-de-alta-e-media-complexidade>. Acesso em: 25 maio 2015.

BRASIL. ANS apresenta mapeamento inédito do ressarcimento ao SUS. Notícias ANS, Rio de Janeiro, 16 dez. 2014a. Disponível em: <http://www.ans.gov.br/aans/noticiasans/integracao-com-o-sus/2706-ans-apresenta-mapeamento-inedito-do-ressarcimento-aosus>. Acesso em: 25 maio 2015.

BRASIL. Boletim informativo: utilização do sistema público por beneficiários de planos de saúde e ressarcimento ao SUS, n. 1, abr. 2016. Rio de Janeiro: Agência Nacional de Saúde Suplementar, n. 1, 2016c. Disponível em: <http://www.ans.gov.br/images/stories/ 
Materiais_para_pesquisa/Materiais_por_assunto/boletim_ressarcimento.pdf > Acesso em: 9 abr. 2016.

BRASIL. Conselho Nacional de Saúde. Resolução $n^{\circ}$ 466, de 12 de dezembro de 2012. Aprova normas regulamentadoras de pesquisas envolvendo seres humanos. Diário Oficial da União. Brasília, 2012.

BRASIL. Conselho Nacional de Secretários de Saúde. Sistema Único de Saúde. Conselho Nacional de Secretários de Saúde. Brasília: CONASS, 2007.

BRASIL. Lei $\mathbf{n}^{\circ} \mathbf{8 . 0 8 0}$, de 19 de setembro de 1990. Dispõe sobre as condições para a promoção, proteção e recuperação da saúde, a organização e o funcionamento dos serviços correspondentes e dá outras providências. Brasília: Senado Federal, 1990 b.

BRASIL. Lei no 9.656, de 3 de junho de 1998. Dispõe sobre os planos e seguros privados de assistência à saúde. Brasília: Senado Federal, 1998.

BRASIL. Lei no 9.961, de 28 de janeiro de 2000. Cria a Agência Nacional de Saúde Suplementar - ANS e dá outras providências. Brasília: Senado Federal, 2000a.

BRASIL. Ministério da Saúde. Secretaria de Atenção à Saúde. Departamento de Atenção Básica. Política Nacional de Alimentação e Nutrição / Ministério da Saúde, Secretaria de Atenção à Saúde. Departamento de Atenção Básica. Brasília: Ministério da Saúde, 2013.

BRASIL. Ministério da Saúde. Secretaria Executiva. Sistema Único de Saúde (SUS): princípios e conquistas. Brasília: Ministério da Saúde, 2000 b.

BRASIL. Ministério da Saúde. Sistema de Informação do Programa Nacional de Imunizações. Disponível em: 〈http://pni.datasus.gov.br/apresentacao.asp〉. Acesso em 14 mar. $2016 b$.

BRASIL. Ministério do Planejamento, Orçamento e Gestão. Secretaria de Gestão Pública. SIAPE - Sistema Integrado de Administração de Recursos Humanos. Brasília, DF: 2016d.

BRASIL. Ministério do Planejamento, Orçamento e Gestão. Secretaria de Gestão Pública. eSIC - Sistema Eletrônico do Serviço de Informações ao Cidadão. Brasília, DF: 2016e, 1 CD-ROM.

BRASIL. Portaria Normativa SRH/MP de 05 de outubro de 2010. Dispõe sobre a assistência à saúde suplementar dos servidores ativos, inativos, seus dependentes e pensionistas. Diário 
Oficial da União, Poder Executivo, Brasília, DF, 13 out. 2010. Seção 1, p. 43-46. Disponível em: <http://portal.in.gov.br/>. Acesso em: 25 maio 2015.

BRASIL. Portaria Normativa SRH/MP No 8 de 14 de janeiro de 2016. Dispõe sobre a participação da União no custeio da assistência à saúde suplementar do servidor e demais beneficiários de que trata a Portaria Normativa SRH n ${ }^{\circ}$ 5, de 11 de outubro de 2010. Diário Oficial da União, n. 9, Seção I, p. 156. Poder Executivo, Brasília, DF, 2016 a.

BRASIL. Regime Jurídico dos Servidores Públicos Civis da União. Lei $n^{\circ}$ 8.112/90 [recurso eletrônico]. 3. ed. Brasília: Câmara dos Deputados: Edições Câmara, 1990a.

BRASIL. Utilização do Sistema Público de Saúde por Beneficiários da Saúde Suplementar. Diretoria de Desenvolvimento Setorial. ANS. Brasília, Dezembro, 2014b.

BRUNI, A. L. SPSS guia prático para pesquisadores. São Paulo: Atlas, 2012.

CAMPOS, G. W. S. A Saúde, o SUS e o programa "Mais Médicos". Revista do Médico Residente, v. 15, n. 2, 2013.

CARVAlHO, G. A saúde pública no Brasil. Estudos Avançados, v. 27, n. 78, p. 7-26, 2013.

COELHO, I. B. Democracia sem equidade: um balanço da reforma sanitária e dos dezenove anos de implantação do Sistema Único de Saúde no Brasil. Ciência \& Saúde Coletiva, v. 15, n. 1, p. 171-183, 2010.

CONHEÇA as operadoras. A Qualicorp é parceira das mais conceituadas operadoras e seguradoras de saúde do Brasil. Apresenta textos informativos sobre várias operadoras de planos de saúde. QUALICORP. Brasília [s.d] Disponível em: < http://www.economizecomaqualicorp.com.br/performance_df/qualicorp/df/naodefinida/?c_c=distritofederal_planosdesaude_search_search_desktop_alwaysondistritofederal_planosdesaude_planosdesaude\&c_p=google \&c_f $=$ search\&gclid=CNr49o247c oCFVIFkQodmUIOGQ\#/Landing> Acesso em: 10 fev. 2016.

CRUZ. J. Estudo do Idec mostra que operadoras de planos de saúde devem ao SUS mais de R\$ 742 milhões. Em Foco, 05 maio 2015. Disponível em: <http://www.idec.org.br/emacao/em-foco/estudo-do-idec-mostra-que-operadoras-de-planos-de-saude-devem-ao-sus-maisde-r-742-milhes>. Acesso em: 07 maio 2015.

DA SILVA, C. L.; ROTTA, C. V. O dilema da universalidade e financiamento público do Sistema Único de Saúde no Brasil. Textos \& Contextos, Porto Alegre, v. 11, n. 2, p. 333$345,2012$. 
DE BARROS, F. P. C.; DE SOUSA, M. F. Equidade: seus conceitos, significações e implicações para o SUS. Saúde e Sociedade, v. 25, n. 1, p. 9-18, 2016.

DOBASHI, B. F.; BRÊTAS JR., N.; SILVA, S. F. O pacto interfederativo na saúde e a gestão descentralizada: uma oportunidade estratégica de promover avanços no Sistema Único de Saúde. In: SANTOS, N. R.; AMARANTE, P. D. C. (Orgs.). Gestão pública e relação público-privado na saúde. Rio de Janeiro: Cebes, 2010. Cap. 1, p. 11-23.

FERRAZ, O. L. M.; VIEIRA, F. S. Direito à saúde, recursos escassos e equidade: os riscos da interpretação judicial dominante. Dados, v. 52, n. 1, p. 223-51, 2009.

FLEURY, S. Judicialização pode salvar o SUS. Saúde em Debate, v. 36, n. 93, p. 159-162, 2012.

FLEURY, S. Revisitando “a questão democrática na área da saúde”: quase 30 anos depois. Saúde em Debate, v. 33, n. 81, p. 156-164, 2009.

GARCIA, L. P. et al. Gastos com planos de saúde das famílias brasileiras: estudo descritivo com dados das Pesquisas de Orçamentos Familiares 2002-2003 e 2008-2009. Ciência \& Saúde Coletiva, v. 20, n. 5, p. 1425-1434, 2015.

GERSCHMAN, S. et al. O papel necessário da Agência Nacional de Saúde Suplementar na regulação das relações entre operadoras de planos de saúde e prestadores de serviços. Physis, Rio de Janeiro, v. 22, n. 2, p. 463-467, 2012.

GERSCHMAN, S. Políticas comparadas de saúde suplementar no contexto de sistemas públicos de saúde: União Européia e Brasil. Ciência \& Saúde Coletiva, v. 13, n. 5, p. 14411451, 2008.

GUERRA, M. Modelo de alocação de recursos do Sistema Único de Saúde para organizações hospitalares: serviços de alta complexidade. Mimeo. 2013.

GUIMARÃES, P. R. B. Métodos quantitativos estatísticos. Curitiba: IESDE Brasil S.A., 2008.

IBGE. Instituto Brasileiro de Geografia e Estatística. Pesquisa Nacional por Amostra de Domicílios. Questionário da pesquisa. Rio de Janeiro: IBGE, 2008.

IBGE. Instituto Brasileiro de Geografia e Estatística. Pesquisa Nacional por Amostra de Domicílios. Um panorama da saúde no Brasil - Acesso e utilização dos serviços, condições de saúde e fatores de risco e proteção à saúde. Rio de Janeiro, v. 33, p.1-133, 2013. 
INSTITUTO DE ESTUDOS DE SAÚDE SUPLEMENTAR. Os custos do ressarcimento ao SUS, ano 1, n. 8, São Paulo, 4 out. 2010. Disponível em: <http://www.iess.org.br/html/ ano1n8.pdf>. Acesso em: 23 abr. 2015.

INSTITUTO FEDERAL DE EDUCAÇÃO, CIÊNCIA E TECNOLOGIA DE GOIÁS. Diretoria de Desenvolvimento de Recursos Humanos/Reitoria. Planilha de Dados Cadastrais dos Servidores Técnico-administrativos e Docentes (4 de janeiro 2016). IFG, 2016.

INSTITUTO FEDERAL DE GOIÁS. Acesso à informação. Disponível em: <http://www.ifg.edu.br/>. Acesso em: 28 ago. 2015.

LIBERDADE de escolha entre as operadoras parceiras, Aliança Administradora. [S.1], 2016. Disponível em: <https://www.aliancaadm.com.br/web/Parceiros/Operadoras.aspx> Acesso em: 10 fev. 2016.

LUIZ, O. C.; JORGE, K. Saúde e direitos: princípios para ação. BIS - Boletim do Instituto de Saúde, São Paulo, v. 12, n. 2, p. 115-121, 2010.

MARTINS, M.; MARTINS, R. Nas eleições de 2016, cada centavo estará em disputa. Carta Capital, São Paulo 25 jan. 2016. Disponível em: <http://www.cartacapital.com.br/revista/ 884/cada-centavo-em-disputa> Acesso em: 12 fev. 2016.

MENDES, A.; WEILLER, J. A. B. Renúncia fiscal (gasto tributário) em saúde: repercussões sobre o financiamento do SUS. Saúde em Debate, v. 39, n. 105, p. 491-505, 2015.

MENICUCCI, T. M. G. História da reforma sanitária brasileira e do Sistema Único de Saúde: mudanças, continuidades e a agenda atual. História, Ciências, Saúde - Manguinhos, p. 7792, 2014.

MENICUCCI, T. M. G. Ruptura e continuidade: a dinâmica entre processos decisórios, arranjos institucionais e contexto político - o caso da política de saúde. Locus: revista de história, Juiz de Fora, v. 15, n. 2, p. 47-69, 2009.

NORONHA, J.; SANTOS, I.; PEREIRA, T. Relações entre o SUS e a saúde suplementar: problemas e alternativas para o futuro do sistema universal. In: SANTOS, N. R.; AMARANTE, P. D. C. (Orgs.). Gestão pública e relação público-privado na saúde. Rio de Janeiro: Cebes, 2011. Cap. 9, p. 152-79.

OCKÉ-REIS, C. O. Gasto privado em saúde no Brasil. Cadernos de Saúde Pública, 2015, v. 31, n. 7, p. 1351-1353, 2015. 
OCKÉ-REIS, C. O. SUS: o desafio de ser único. In: SANTOS, N. R.; AMARANTE, P. D. C. (Orgs.). Gestão pública e relação público-privado na saúde. Rio de Janeiro: Cebes, 2010. Cap. 6, p. 101-114.

ORGANIZAÇÃO MUNDIAL DA SAÚDE (OMS). Financiamento dos sistemas de saúde: o caminho para a cobertura universal. Relatório mundial de saúde. Genebra: OMS, 2010.

PAIM, J. A Constituição Cidadã e os 25 anos do Sistema Único de Saúde (SUS). Cadernos de Saúde Pública, v. 29, n. 10, p. 1927-1936, 2013.

PAIM, J. et al. O sistema de saúde brasileiro: história avanços e desafios. 2011. Saúde no Brasil, v. 1, 2012.

PAIM, J. O que é o SUS. Rio de Janeiro: Fiocruz, 2009b.

PAIM, J. S. Reforma Sanitária Brasileira: avanços, limites e perspectivas. In: MATTA, Gustavo Corrêa: LIMA, Júlio César França. Estado, sociedade e formação profissional em saúde: contradições e desafios em 20 anos de SUS, v. 20, p. 91-122, 2009a.

PAIM, J. S.; Silva, L. M. V. D., Lígia Maria Vieira da. Universalidade, integralidade, equidade e SUS. BIS - Boletim do Instituto de Saúde, São Paulo, v. 12, n. 2, p. 109-114, 2010.

PAIM, J.; TEIXEIRA, C. F. Configuração institucional e gestão do Sistema Único de Saúde: problemas e desafios. Ciência \& Saúde Coletiva, v. 12, p. 1819-1829, 2007.

PIRES, M. R. G. M. et al. Fatores associados à atenção domiciliária: subsídios à gestão do cuidado no âmbito do SUS. Revista da Escola de Enfermagem da USP, São Paulo, v. 47, n. 3, jun. 2013. Disponível em: <http://www.scielo.br/scielo.php?script=sci_arttext\&pid=S008062342013000300648>. Acesso em: 21 mar. 2016.

PIRES, M. R. G. M. et al. Oferta e demanda por média complexidade/SUS: relação com atenção básica. Ciência \& Saúde Coletiva, v. 15, n. Supl 1, p. 1009-1019, 2010. Disponível em: <http://repositorio.unb.br/handle/10482/2336>. Acesso em: 21 mar. 2016.

PONTE, C. F.; FALLEIROS, I. Na corda bamba de sombrinha: a saúde no fio da história. Fiocruz, 2010.

PORTUGAL. Administração Central de Serviços de Saúde [ACSS] (2016). Circular Normativa n. 08/2016. Alteração do regulamento de aplicação de Taxas Moderadoras. Disponível em: <http://www.acss.min-saude.pt/Portals/0/Circular\%20N\%C2\%BA\%208\%20$\% 20$ Normativa.pdf $>$. Acesso em: 23 mar. 2016. 
SÁ, B. et al. Capital Estrangeiro nos Serviços de Assistência à Saúde e Seus Riscos. In: BRASIL em desenvolvimento, IPEA Brasil. Estado, planejamento e políticas públicas. Brasília: IPEA, 2015.

SAMPIERI, R. H.; COLLADO, C. F.; LUCIO, M. D. P. B. Metodologia de pesquisa. 5. ed. Porto Alegre: Penso, 2013.

SANCHEZ, R. M.; CICONELLI, R. M. Conceitos de acesso à saúde. Revista Panamericana de Salud Pública, v. 31, n. 3, p. 260-268, 2012.

SANTOS, A. M.; GIOVANELLA, L. et al. Desafios organizacionais para fortalecimento da Atenção Primária à Saúde em Portugal. Revista Brasileira de Educação Médica, Rio de Janeiro, v. 39, n. 3, p. 359-369, set. 2015.

SANTOS, I. S. O mix público-privado no sistema de saúde brasileiro: elementos para a regulação da cobertura duplicada. Rio de Janeiro, Escola Nacional de Saúde Pública Sergio Arouca - ENSP, 2009. Tese de Doutorado.

SANTOS, N. R.; AMARANTE, P. D. C. (Orgs.). Gestão pública e relação público-privado na saúde. Rio de Janeiro: Cebes, 2010.

SCHEFFER, M. O capital estrangeiro e a privatização do sistema de saúde brasileiro. Cadernos de Saúde Pública, v. 31, n. 4, p. 1-4, 2015 a.

SCHEFFER, M.; BAHIA, L. Representação política e interesses particulares na saúde: a participação de empresas de planos de saúde no financiamento de campanhas eleitorais em 2014. Relatório de pesquisa, 2015b. Disponível em: <http://www.abrasco.org.br/site/wpcontent/uploads/2015/02/Planos-de-Saude-e-Eleicoes-FEV-2015-1.pdf>. Acesso em: 08 fev. $2015 b$.

SCHEFFER, M.; AZEVEDO, G.; BAHIA, L. Aporte de recursos públicos para planos privados de saúde. In: SANTOS, N. R.; AMARANTE, P. D. C. (Orgs.). Gestão pública e relação público-privado na saúde. v. 1. Rio de Janeiro: Cebes, 2010. p. 220-242.

SCHEFFER, M.; BAHIA, Lígia. O financiamento de campanhas pelos planos e seguros de saúde nas eleições de 2010. Saúde em Debate, v. 37, n. 96, p. 96-103, 2013.

SESTELO, J. A. de F.; SOUZA, L. E. P. F. de; BAHIA, L. Saúde suplementar no Brasil: abordagens sobre a articulação. Cadernos de Saúde Pública, v. 29, n. 5, p. 851-866, 2013. 
SILVA JUNIOR, S. D.; COSTA, F. J. Mensuração e Escalas de Verificação: uma Análise Comparativa das Escalas de Likert e PhraseCompletion. PMKT - Revista Brasileira de Pesquisas de Marketing, Opinião e Mídia, São Paulo, v. 15, p. 1-16, out. 2014.

SOUZA, M. A. de; SALVALAIO, D. Rede própria ou rede credenciada: análise comparativa de custos em uma operadora brasileira de planos de saúde. Revista Panamericana de Salud Pública [online]. 2010, v. 28, n. 4, p. 305-310.

SOUZA, M. S. Uma agenda pelo direito universal à saúde. In: Em defesa do SUS universal e igualitário. Le Monde Diplomatique Brasil. São Paulo. 12 dez. 2015. Disponível em: <http://www.diplomatique.org.br/upload/encartes/encarte_SUS_12_2015.pdf>. Acesso em 21 jan. 2016.

TEIXEIRA, C. F. Os princípios do Sistema Único de Saúde. Texto de apoio elaborado para subsidiar o debate nas Conferências Municipal e Estadual de Saúde. Salvador, jun. 2011.

TRAVASSOS C.; CASTRO, M. S. M. Determinantes e desigualdades sociais no acesso e na utilização de serviços de saúde. In: Giovanella L., Escorel S., Lobato I.V., Carvalho A.I., Noronha J. C. Políticas e sistemas de saúde no Brasil. 2. ed. Rio de Janeiro: Fiocruz; 2012. p. 183-206.

TRAVASSOS, C.; VIACAVA, F.; LAGUARDIA, J. Os suplementos saúde na Pesquisa Nacional por Amostra de Domicílios (PNAD) no Brasil. Revista Brasileira de Epidemiologia, v. 11, supl. 1, p. 98-112, 2008.

TRAVASSOS, C.; MARTINS, M. Uma revisão sobre os conceitos de acesso e utilização de serviços de saúde. Cadernos de Saúde Pública, v. 20, n. sup. 2, p. S190-S198, 2004.

VERGARA, S. C. Projetos e relatórios de pesquisa em administração. São Paulo: Atlas, 1998. 


\section{APÊNDICE I - Questionário online}

02/03/2016

\section{Análise da Utilização do Sistema Único de Saúde por Servidores Públicos Federais que Possuem Planos Privados de Saúde \\ *Obrigatório}

Prezado(a) servidor(a),

Estamos realizando uma pesquisa sobre Planos de Saúde Privados e Sistema Único de Saúde (SUS) no curso de Mestrado Profissional em Gestão Pública da Universidade de Brasília (UnB). Contamos com a sua colaboração para responder a um questionário breve e objetivo. O tempo médio de resposta é de 5 a 10 minutos. Sua contribuição será importante para avançarmos no acesso à saúde no SUS

Sem mais, agradecemos-lhe imensamente pela colaboração.

Respeitosamente,

Aluno: Francisco de Assis Costa e Silva, matrícula n 140122796

Servidor do Instituto Federal de Educação, Ciência e Tecnologia de Goiás, Câmpus Luziânia

\section{Termo de Consentimento Livre e Esclarecido (TCLE)}

Esta pesquisa tem como objetivo geral analisar os principais motivos da procura pelos serviços públicos de saúde do SUS por servidores ativos do Instituto Federal de Educação, Ciência e Tecnologia de Goiás (IFG) que possuem planos privados de saúde e as repercussões desta situação para a duplicidade do gasto público em saúde. A pesquisa foi autorizada pelo IFG e lhe garantimos: 1-solicitar, a qualquer momento, maiores esclarecimentos sobre a investigação pelo telefone: (061) 9683-2598; e-mail: francisco.ifgluz@gmail.com; 2-segredo absoluto sobre seus dados e quaisquer outras informações que possam levar à identificação pessoal; 3-ampla possibilidade de negar-se a participar da pesquisa, a responder a quaisquer questões ou a fornecer informações que julgar prejudicial à sua integridade física, moral e social; 4-solicitar exclusão de parte das falas e/ou de declarações de documento oficial ou de divulgação o que será prontamente atendido; 5-desistir, a qualquer tempo, de participar da pesquisa. Os resultados do estudo serão publicados em sites, revistas e eventos científicos, apresentados para docentes, discentes, profissionais, equipes técnicas, gestores das secretarias e público interessado em geral. Contudo, cabe ressaltar que os participantes não serão identificados.

Universidade de Brasília (UnB) Faculdade UnB Planaltina (FUP) Programa de Mestrado Profissional em Gestão Pública (PPGP) Profa. Phd. Maria Raquel Gomes Maia Pires (Orientadora) Professora Adjunta/Departamento de Enfermagem/FS/UnB

Aluno: Francisco de Assis Costa e Silva, matrícula nº 140122796 Servidor do IFG Câmpus Luziânia

1. *

Marcar apenas uma oval.

Aceito participar da pesquisa Ir para a pergunta 2.

Não aceito participar da pesquisa Ir para "MUITO OBRIGADO!". 
02/03/2016 Análise da Utilização do Sistema Único de Saúde por Servidores Públicos Federais que Possuem Planos Privados de Saúde 2. Possui plano privado de saúde? *

Marcar apenas uma oval.

Sim. Sou o titular.

Sim. Sou dependente.

Não possuo plano de saúde. Ir para a pergunta 17.

3. Você e/ou seu dependente no plano de saúde utilizaram os serviços de saúde do SUS nos últimos 6 meses? *

Marcar apenas uma oval.

$\int \operatorname{Sim}$.

Não. Ir para a pergunta 17.

4. Em qual Estado e Município você e/ou

seu dependente no plano de saúde

buscaram atendimento no SUS? *

Informar UF e Município

5. Qual o serviço de saúde do SUS que você e/ou seu dependente no plano de saúde buscou? *

Marque todas que se aplicam

Unidade Básica de Saúde (posto ou centro de saúde)

Ambulatórios ou serviços especializados

Unidades de Pronto-Atendimento (UPA), (pronto socorro ou emergência de hospital)

Atenção domiciliar da Estratégia Saúde da Família (ESF)

Atenção domiciliar do Núcleo de Apoio à Estratégia Saúde da Família (NASF)

Atenção domiciliar de uma Equipe de Atenção Domiciliar do SUS

Outro: 
6. Qual o problema de saúde que você ou seu dependente tinham no momento da procura pelo serviço do SUS? *

Marque todas que se aplicam.

Afecções agudas leves (gripes, amigdalites, dermatite, bronquites leves, tosse, febre, conjuntivite, dor lombar, vômito, diarréia, dor de estômago, dor no corpo, dor de dente, distúrbio nutricional, Doença Sexualmente Transmissível (DST))

Afecções agudas de moderadas à graves (crise asmática, pico hipertensivo, cardiopatias, infecção urinária, cólica renal, sintomatologia do infarto, abcesso dentário, Doença Pulmonar Obstrutiva Crônica (DPOC), tumor/câncer)

Condições crônicas de saúde (Hipertensão, diabetes, tuberculose, hanseníase, gravidez e demais situações que dependem de atendimentos de saúde por longos períodos)

Acidente (fraturas, ingestão de corpo estranho, etc)

Lesão (picada de inseto, cortes na pele, entorse, luxações, etc)

Retorno (cirurgia, parto, consultas de rotina e controle)

Controle de agravos (tuberculose, hanseniase, diabetes, hipertensão, doença de chagas, prevenção de câncer, DST)

Outro:

\section{ATENÇÃo BÁSICA}

Por favor, marque todos os procedimentos que você e/ou seu dependente receberam nos serviços do SUS

Marque todas que se aplicam.

Consultas médicas (generalista, ESF, clínico, pediatra, ginecologista)

Consultas odontológicas

Ações executadas por outros profissionais de nível superior

Procedimentos médicos em pele e mucosas

Consultas de enfermagem (nível superior)

Procedimentos de enfermagem/atendimentos de nível médio/auxiliar de enfermagem (curativos, retirada de pontos, aferir pressão, glicemia, inalações)

Procedimentos Odontológicos/nível médio

Grupos/Atividades Educativas

Acolhimento

Classificação de risco (UPA)

Práticas Complementares (homeopatia, acupuntura, fitoterapia, etc)

Ações programáticas - Saúde da Mulher (pré-natal, preventivo, planejamento familiar, etc)

Ações programáticas - Saúde da Criança/Crescimento e Desenvolvimento (CD), vacinação, palestras, etc

Ações programáticas - Saúde do Adulto e do idoso (Controle da Hipertensão e Diabetes, Programa Tuberculose, DST/AIDS, etc)

Outro: 


\section{MÉDIA COMPLEXIDADE}

Por favor, marque todos os procedimentos que você e/ou seu dependente receberam nos serviços do SUS

Marque todas que se aplicam.

Consultas médicas com especialistas (gastroenterologista, ortopedista, cirurgião, cardiologista, etc)

Procedimentos ambulatoriais especializados (Procedimentos ginecológicos, cirurgias gerais, de mama, procedimentos/cirurgias do aparelho visual, digestivo, auditivo, de pele, tecidos)

Procedimentos hospitalares especializados (Procedimentos ginecológicos, obstétricos, cirurgias gerais, de mama, procedimentos/cirurgias do aparelho visual, digestivo, auditivo, de pele, tecidos subcutâneos e mucosa, sistema ortoarticular, aparelho digestivo e anexos/parede abdominal, circulatório, nervoso, atendimento à queimados)

Procedimentos traumato-ortopédicos

Exames de patologia clínica (Bioquímica, coprologia, hematologia, imunologia, microbiologia, urina, micologia, LCR (Liquor), esperma, líquido amniótico, Líquido sinovial e derrames, suco gástrico, exames diagnóstico em geriatria, patologia clínica ocupacional, medicina nuclear in vitro)

Exames de Anatomopatologia e Citopatologia

Diagnóstico por imagem (Ultra-sonografias, ecocardiografia, endoscopia, Eletrocardiograma (ECG), Eletroencefalograma (EEG), RX)

Reabilitação (fisioterapia, prótese, órtese)

Outro:

9. Internação: Por favor, especifique a clínica:

(Cirúrgica, médica, pediátrica, obstétrica, outras)

10. Quanto tempo levou para ser completamente atendido no SUS do momento que chegou até o término do último procedimento?

Caso tenha ficado internado, considerar o atendimento até o momento de entrada no apartamento.

Marcar apenas uma oval.

Menos de $30 \mathrm{~min}$

De $31 \mathrm{~min}$ a $1 \mathrm{~h}$

De $1 \mathrm{~h}$ a $2 \mathrm{~h}$

De $2 \mathrm{~h}$ a $4 \mathrm{~h}$

De $4 \mathrm{~h}$ a $6 \mathrm{~h}$

De $6 \mathrm{~h}$ a $8 \mathrm{~h}$

Mais de $8 \mathrm{~h}$ 
02/03/2016 Análise da Utilização do Sistema Único de Saúde por Servidores Públicos Federais que Possuem Planos Privados de Saúde 11. ALTA COMPLEXIDADE

Por favor, marque todos os procedimentos que você e/ou seu dependente receberam nos serviços do SUS

Marque todas que se aplicam.

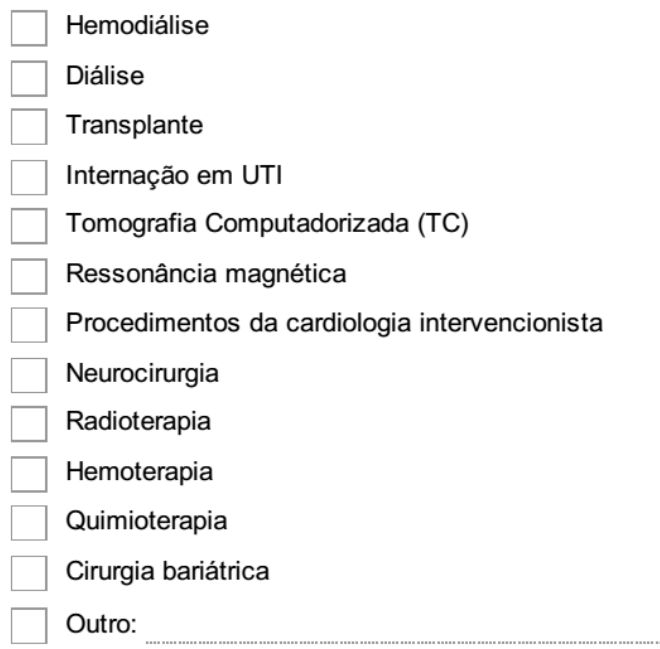

12. Você sabia que o seu plano de saúde deve ressarcir ao SUS o valor de todos os procedimentos que você realizou nos serviços públicos de saúde? *

Marcar apenas uma oval.

$\bigcirc \operatorname{Sim}$

Não

13. Considerando a sua experiência com os serviços do SUS que você utilizou, como você avalia o atendimento recebido: *

1- Péssimo; 2- Ruim; 3- Indiferente; 4- Regular; 5- Ótimo Marcar apenas uma oval.

$\begin{array}{llllll}1 & 2 & 3 & 4 & 5 & \\ \text { Péssimo } \square \longrightarrow \square & \square\end{array}$

14. Você voltaria a utilizar os serviços do SUS? * Marcar apenas uma oval.

Sim.

Não. 
16. Informe os motivos de ter procurado os atendimentos acima no SUS e não por meio do plano de saúde *

Marque todas que se aplicam.

\section{Carência do plano de saúde}

O plano de saúde não oferta os serviços procurados

Falta de cobertura do plano de saúde

Recursos hospitalares precários e/ou insuficientes oferecidos pelo plano de saúde

Por ter direito à saúde pública

Confiabilidade no SUS

Outro:

\section{INFORMAÇÕES COMPLEMENTARES APENAS DO(a)}

\section{SERVIDOR(a)}

17. Câmpus de lotação no IFG * Marcar apenas uma oval.

Anguas Lindas
Anápolis
Cidade de Goiás
Formosa
Goiânia
Goiânia Oeste
Inhumas
Itumbiara
Jataí
Luziânia
Reitoria
Senador Canedo
Uruaçu
Valparaíso


02/03/2016 Análise da Utilização do Sistema Único de Saúde por Servidores Públicos Federais que Possuem Planos Privados de Saúde 18. Denominação do cargo no IFG *

Informe sua profissão

19. Informar o último nível de educação concluído *

Marcar apenas uma oval.
Ensino Fundamental
Ensino Médio
Ensino Médio + Curto Técnico
Graduação
Especialização
Mestrado
Doutorado
Outro:

20. Sexo *

Marcar apenas uma oval.

Feminino

Masculino

21. Idade *

\section{Remuneração *}

Marcar apenas uma oval.
$R \$ 1.500$ a 2.499
$\mathrm{R} \$ 2.500$ a 3.499
$\mathrm{R} \$ 3.500$ a 4.499
$\mathrm{R} \$ 4.500$ a 5.499
$\mathrm{R} \$ 5.500$ a 6.499
$R \$ 6.500$ ou mais

MUITO OBRIGADO!

Clique em enviar para registrar a sua participação 